\title{
CEsifo \\ WORKING

\section{Intraday Effect of News on Emerging European Forex Markets: An Event Study Analysis}

Evžen Kočenda, Michala Moravcová 


\section{Impressum:}

CESifo Working Papers

ISSN 2364-1428 (electronic version)

Publisher and distributor: Munich Society for the Promotion of Economic Research - CESifo $\mathrm{GmbH}$

The international platform of Ludwigs-Maximilians University's Center for Economic Studies and the ifo Institute

Poschingerstr. 5, 81679 Munich, Germany

Telephone +49 (o)89 2180-2740, Telefax +49 (o)89 2180-17845, email office@cesifo.de

Editors: Clemens Fuest, Oliver Falck, Jasmin Gröschl

www.cesifo-group.org/wp

An electronic version of the paper may be downloaded

- from the SSRN website: $\quad$ www.SSRN.com

- from the RePEc website: $\quad$ www.RePEc.org

- from the CESifo website: www.CESifo-group.org/wp 


\title{
Intraday Effect of News on Emerging European Forex Markets: An Event Study Analysis
}

\begin{abstract}
We analyze the impact of Eurozone/Germany and U.S. macroeconomic news announcements and the communication of the monetary policy settings of the ECB and the Fed on the forex markets of new EU members. We employ an event study methodology to analyze intra-day data from 2011-2015. Our comprehensive analysis of the wide variety of macroeconomic information during the post-GFC period shows that: (i) macroeconomic announcements affect the value of the new-EU-country exchange rates, (ii) the origin of the announcement matters, (iii) the type of announcement matters, (iv) different types of news (good, bad, or neutral) result in different reactions, (v) markets react not only after the news release but also before, (vi) when the U.S. dollar is a base currency the impact of the news is larger than in the case of the euro, (vii) announcements on ECB monetary policy result in stronger effects than those of the Fed, (viii) temporary inefficiencies are present on new-EU-country forex markets, (ix) new-EUcountry exchange rates react differently on positive US news during the EU debt crisis when compared to the rest of the period.
\end{abstract}

JEL-Codes: C520, F310, F360, G150, P590.

Keywords: foreign exchange markets, intraday data, abnormal returns, event study, macroeconomic announcements, monetary policy settings, European Union, new EU members.

\author{
Evžen Kočenda* \\ Institute of Economic Studies \\ Charles University \\ Opletalova 26 \\ Czech Republic - 11000 Prague \\ evzen.kocenda@fsv.cuni.cz
}

\author{
Michala Moravcová \\ Institute of Economic Studies \\ Charles University \\ Opletalova 26 \\ Czech Republic - 11000 Prague \\ moravcovamichala@gmail.com
}

*corresponding author

We are thankful for comments from Ali Kutan (Editor), Gerhard Illing, Lucjan Orlowski, Pedro Piccoli, two anonymous referees, and participants at several presentations. We acknowledge support from GAČR grant No. 16-09190. The usual disclaimer applies. 


\section{Introduction and related literature}

We analyze how the emerging European forex markets react to foreign macroeconomic news and the monetary policy settings of the major central banks. Developments in macroeconomic fundamentals are evidenced to be quite important for exchange rate movements (Cavusoglu, 2011). Their effects on exchange rates materialize via macroeconomic news (Andersen et al., 2003), whose releases produce substantial exchange rate variation (Fratzscher, 2006; Laakonen, 2007). The available evidence comes mostly from developed markets (Neely and Dey, 2010), while emerging markets are much less explored, and the evidence from emerging European forex markets is downright scarce. This is quite surprising because new European Union (EU) markets are documented to be quite important for international portfolio diversification (Jotikasthira et al., 2012; Wang and Bilson, 2017). ${ }^{1}$ Further, while the effects of news on mature forex markets are well established, the potential reaction of the new EU currencies to foreign macro news might be less than obvious; their reaction to shocks in the U.S. dollar varies greatly (Orlowski, 2012), but at the same time there exist positive and increasing co-movements between the euro and the new EU currencies (Orlowski, 2016).

The world forex market is responsive to a vast amount of information in the form of macroeconomic and monetary news, as surveyed by Neely and Dey (2010). News originating in large economies is empirically shown to matter most. Faust et al. (2003), Andersen et al. (2003), and Chaboud et al. (2004) evidence the importance of U.S. news releases. Ehrmann and Fratzscher (2005), Cakan et al. (2015), and Gilbert et al. (2016) show that both U.S. and European news releases have significant effects on pricing on forex markets and on financial markets in general (for recent evidence on other classes of assets see for example Savor and Wilson, 2013; or Lucca and Moench, 2015).

There is also similar recent evidence on the impact of news on emerging (financial) markets (Andritzky et al., 2007; Fedorova et al., 2014), including emerging European markets (Hanousek et al., 2009; Hanousek and Kočenda, 2011; Büttner et al., 2012). That evidence centers chiefly on stock markets, though.

Analyses of how macroeconomic and monetary news impact the emerging European forex markets are rare. Scalia (2008; p. 544) finds only a weak effect of public news on the

\footnotetext{
${ }^{1}$ According to Jotikasthira et al. (2012), new EU markets are important for the portfolio diversification of mutual and hedge funds domiciled mainly in developed markets. They show 270 active funds in the Czech Republic, 276 funds in Poland, and 295 funds in Hungary after the crisis. What is more important, these fund holdings account for $3.6 \%$ of the float-adjusted market capitalization in the Czech Republic, $8.6 \%$ in Hungary, and $4.7 \%$ in Poland; this is more than $2.6 \%$ of the average number of free-float market capitalization in 25 emerging markets examined by Jotikasthira et al. (2012). Wang and Bilson (2017) show that Eastern European emerging bond market returns exhibit low correlations with traditional fixed income investments and thus offer opportunities for portfolio diversification.
} 
Czech koruna (CZK) exchange rate but suggests to analyze "the distinct news items and their 'surprise' component". Further, Égert (2007) uses event study methodology to show that central bank interventions coupled with communications (and backed by interest rate news), have a significant effect on the exchange rate of the Czech, Hungarian, and Polish currencies. A more detailed exercise is conducted by Égert and Kočenda (2014), who analyze the newEU forex markets and divide their analysis into the pre-crisis (2004-2007) and crisis (20082009) periods. They show that, before the crisis, several types of macroeconomic news impact forex markets, but during the crisis the relationships break down and the currencies react only to news on the key economic indicator (real GDP growth) and do not react to other macro announcements. The responsiveness of the currencies to central bank verbal interventions follows a slightly different pattern: exchange rate-related verbal communications of central banks matter when markets experience high uncertainty (crisis), while during calmer days markets are less attentive. In this respect Égert and Kočenda (2014) show that important news do not always produce significant effects on exchange rates.

However, to the best of our knowledge, so far there are no studies that analyze the impact of macroeconomic and monetary news on the emerging European forex markets after the 2007 crisis Hence, it is legitimate to ask relevant questions arising with respect to the propagation of news in the new-EU forex markets. Do specific news-in terms of type and quality - exhibit a markedly different impact? Is the impact dependent on the base currency? What is the duration of the impact? Are the new-EU forex markets efficient when new information arrives?

In this paper we differentiate from the existing literature in that we explore an underresearched segment of the emerging European forex market during the post-crisis period. In this, we contribute to the literature in several ways. We analyze how three new-EU currencies (the Czech koruna, Polish zloty, and Hungarian forint) react to a large set of foreign macroeconomic news and changes in ECB and Fed monetary policy settings. Because of the underlying economic links between the new-EU and old-EU countries (Hayo et al., 2010), as well as with the U.S., we examine both Eurozone and U.S. macroeconomic announcements and the exchange rates denominated with respect to the euro and the U.S. dollar. Macroeconomic data are a very important source of information not only for the actual state of real economies, but more importantly for their future prospects. For this reason, we examine both traditional macroeconomic announcements (GDP, Trade Balance, Industrial Production, Retail Sales, NFP, CPI, PPI, and Core Durable Goods orders) and also forwardlooking indicators on the economic climate and prospects (PMI, ZEW, and Ifo indices). We 
also assess the impact of the key monetary announcements as they are shown to be important on the forex market in general (Neely and Dey, 2010). Because the post-2008 period is not covered well, we employ intra-day, one-minute data and cover a relatively long post-crisis period of 2011-2015.

In terms of methodology, most of the related research employs a GARCH-type modeling approach. However, the vast amount of daily or even intraday data dwarf the relatively limited number of announcements and this disproportion makes this technique disadvantageous. Rather we opt for the event study approach in order to accurately assess the "surprise component" of the qualitatively different good, bad, and neutral news, and the effect of monetary policy settings on exchange rates. The technique is more suitable for our study because it enables targeting the effect of specific macro news as well as monetary announcements over a precisely defined time interval (Gürkaynak and Sack, 2005; Bredin et al., 2009; Wongswan, 2009; Rai and Suchanek, 2014). ${ }^{2}$ Further, systematically detected nonzero abnormal returns that persist after a particular type of event are inconsistent with market efficiency.

Our key results provide a comprehensive account of how new information entering the emerging EU forex markets propagate during the post-GFC period and can be summarized in the following points. We show that (i) macroeconomic announcements affect the value of the exchange rates of the new EU countries, (ii) the origin of the announcement matters, (iii) the type of the announcement matters, (iv) different types of news (good, bad, or neutral) result in different reactions, (v) markets react not only after the news release, but also before, (vi) when the U.S. dollar is a base currency, the impact of news is larger than in the case of the euro, (vii) announcements on ECB monetary policy result in stronger effects than those of the Fed, (viii) temporary inefficiencies are present on the forex markets of new EU countries, (ix) new-EU-country exchange rates react differently on positive US news during the EU debt crisis when compared to the rest of the period.

The rest of the paper is organized as follows. In Section 2 we describe our data on exchange rates, macroeconomic announcements and central banks' monetary policy. We introduce the event study methodology and formulate our hypotheses in Section 3. Our detailed results are brought forth and discussed in Section 4 that is followed by conclusions.

\footnotetext{
${ }^{2}$ Other studies that applied the event study methodology on emerging markets are, for example, Gurgul and Wójtowicz (2014), Égert (2007), Naidu (2011), Leon and Williams (2012), and Menkhoff (2013).
} 


\section{Data: sources, description, and characteristics}

We intentionally deviate from standard practice and introduce the data before outlining our methodology. The reason is that when we describe our use of event study methodology in Section 3, we need to refer to some specific details related to announcement releases.

\subsection{Forex data}

We analyze six exchange rates $(R)$ of three new-EU currencies (the Czech koruna (CZK), Hungarian forint (HUF), and Polish zloty (PLN)) quoted with respect to the euro (EUR) and the U.S. dollar (USD); for example CZK/EUR denotes exchange rate between amount of Czech currency per 1 euro. The set of six independently quoted intraday one-minute exchange rates is taken from MetaQuotes corresponding to the CET time zone for the period beginning on January 3, 2011 and ending on December 31, 2015. Raw data $\left(R_{t}\right)$ are transformed into a log-difference stationary series of percentage exchange rate returns $\left(r_{t}\right)$ :

$$
r_{t}=\left(\ln R_{t+1}-\ln R_{t}\right) * 100
$$

Thus, a negative change in an exchange rate means an appreciation of the quoting currency $i$ (CZK, HUF, PLN) with respect to the reference currency $j$ (EUR, USD); from a perspective of a forex trader appreciation means a positive return because less units of the quoting currency is needed to buy 1 unit of the reference currency. Conversely, a positive change represents a depreciation of the quoting currency; depreciation means a negative return. Since the EUR/USD is the most heavily traded currency pair globally, we assume that price changes in EUR/USD exchange rate are directly reflected in prices of EUR-denominated and USDdenominated exchange rates and prevent market from arbitrage opportunities. This way the effect of the EUR/USD on new-EU currencies is effectively accounted for. In this respect we follow the approach of Cai et al. (2009) who examine the impact of the U.S. and local news announcement on forex emerging markets or Caporale at al. (2017) who analyze the effects of news on the exchange rates vis-a-vis both the US dollar and the euro for the currencies of the BRICS.

In Figures 1-2 we present the dynamics of the exchange rates under research. All three examined CEE currencies depreciated against the U.S. dollar during the examined time period (2011-2015). At the same time, the Czech crown and Hungarian forint weakened relative to the euro. On the contrary, the Polish zloty has been resilient to the euro and has kept its value. All three of the examined new EU countries use a free-floating exchange rate regime with independent central banks aiming for price stability. The big spike in CZK/EUR and 
CZK/USD daily returns shows the start of exchange rate interventions. The Czech National Bank (CNB) decided to use the exchange rate as a monetary policy instrument and have performed foreign exchange interventions since November 7, 2013 to prevent the excessive appreciation of the koruna below CZK 27/EUR. On the weaker side of the CZK 27/EUR level, the CNB is allowing the koruna exchange rate to float.

In terms of volatility, the exchange rates of the new-EU-country currencies with respect to the U.S. dollar are generally more volatile than with respect to the euro. ${ }^{3}$ This can be explained by the closer economic connection of the new EU countries to Germany, or the $\mathrm{EU}$ in general, especially with respect to international foreign trade and foreign direct investment. Still, the most volatile currency is the Hungarian forint. The volatility of the Czech koruna is the lowest among the new-EU-country currencies.

\subsection{Macroeconomic announcements}

We gathered data on macroeconomic announcements coming from the Eurozone/Germany and the U.S.A. An extensive data set on 22 different macroeconomic announcements (news) from both regions is divided into four main categories. The Eurozone/Germany data set contains announcements on (i) business climate (Markit's Purchasing Managers' Index (PMI) from the Manufacturing and Services sectors, the German Business Climate Index, and the German ZEW Economic Sentiment Index), (ii) the real economy (Industrial Production, GDP, Retail Sales, and Trade Balance), (iii) prices (measured by CPI and PPI), and (iv) monetarytype indicators represented by central bank announcements of key interest rate changes and monetary policy settings. ${ }^{4}$ In total we employ six German macroeconomic indicators (Ifo, ZEW, PMI indices from the Manufacturing and Services sectors, Industrial Production, and GDP) and four indicators related to the Eurozone economy (CPI, PPI, Trade Balance, and Retail Sales). ${ }^{5}$

\footnotetext{
${ }^{3}$ With regard to market volatility, we acknowledge that the Chicago Board Options Exchange SPX Volatility Index (VIX) stayed at relatively low levels during the period under research. However, Barunik et al. (2017) show that connectedness on the forex market was high during 2008-2010, was somewhat lower during 20112012, and increased during 2013-2015. This evidence means that while the overall market volatility might be relatively low, there were substantial volatility spillovers among currencies on the forex market during most of the time covering the span of the current research.

${ }^{4}$ There are two versions of the CPI report released about two weeks apart: Flash and Final. We consider the Flash report, which is extremely early and therefore tends to have a significant impact. There are also two versions of the GDP report released approximately 10 days apart: preliminary and final. The preliminary release is the earliest and thus tends to have a larger impact. We examine the data for the preliminary GDP release.

${ }^{5}$ Germany's PMI indices are preferred to the Eurozone's because they are published 30 minutes earlier. We expect the primary market reaction to the data released first. German GDP is published three hours before the aggregate GDP from the Eurozone. For this reason, we expect the primary market reaction to be on Germany's data. As for the Ifo and ZEW indices, they do not have a composite Eurozone equivalent. Industrial Production is
} 
The U.S. macroeconomic indicators are also divided into four categories. These are announcements on (i) business climate (Purchasing Managers' Index (PMI) from the Manufacturing and Services sectors provided by ISM), (ii) the real economy (Industrial Production, GDP, Retail Sales, Trade Balance, Core Durable Goods Orders, and Non-farm Payrolls), (iii) prices (measured by CPI and PPI), and (iv) monetary-type indicators represented by central bank announcements of key interest rate changes and monetary policy settings. ${ }^{6}$

The macroeconomic announcements used in this paper are reported by Reuters with a clearly defined calendar, the timing of news releases, and the market expectations of specific news. The so-called consensus forecast of financial market analysts constitutes a proxy for market expectations. We follow Andersen et al. (2007) and define the surprise news variable $\left(x n_{i t}\right)$ as:

$$
x n_{i t}=\left(s n_{i t}-\mathrm{E}_{t-1}\left[s n_{i t}\right]\right) / \sigma_{i},
$$

where $s n_{i t}$ stands for the value or extent of the Reuters scheduled announcement $i$ at time $t$, $E_{t-1}\left[s n_{i t}\right]$ is the value of the announcement for time $t$ expected by the market (market consensus) at time $t-1$, and $\sigma_{i}$ is the sample standard deviation of announcement $i$. The standardization does not affect the properties of the coefficients' estimates as the sample standard deviation $\sigma_{i}$ is constant for any announcement indicator $i$. This approach allows us to divide all releases into three clusters of surprise announcements: better than expected (good news), worse than expected (bad news), and in line with consensus (neutral news).

The reaction of exchange rates to news might not be always clear. First, while an exchange rate-based contract might be considered a single instrument, an announcement impacts the relative price of the two currencies. Second, under the prevailing economic conditions, an announcement considered good news in one country might not be the same in another country. For that reason, we refrain from forming overly specific expectations of the effects of announcements on abnormal exchange rate returns. However, in accord with the relevant literature, we can say that in case of the PMI Manufacturing index, the PMI Services index, the German Ifo Business Climate Index, the German ZEW Economic Sentiment Index, Retail Sales, Trade Balance, Core Durable Goods Orders, GDP, NFP, and Industrial Production, an announcement above the consensus (good news) is expected to have a positive

the key feature of the German economy. We prefer aggregate CPI and PPI from the Eurozone even if they are published a few days after the German indices, because they are the key indicators followed by ECB monetary policy. Even if Germany is the largest economy of the Eurozone, aggregate Retail Sales and Trade Balance published a few days after Germany may produce different results than only the German data.

${ }^{6}$ We prefer the NFP announcement to the unemployment rate number because Andersen et al. (2007) showed that Non-farm Payrolls is one of the most significant macroeconomic announcements. 
impact on the quoting currency (Ramchander et al., 2008), whereas CPI or PPI above the forecast (bad news) is expected to have a negative impact on the quoting currency (Ehrman and Fratzscher, 2005). The same logic applies for the opposite surprises.

We provide a comprehensive overview of the employed news in Table 1; it includes the release date and time as well as the sequencing of the news. The sequence in which macroeconomic data is announced may play an important role in market reaction. Indicators published at the beginning of the month may attract more investor attention and market reaction than those published at the end of the month (Andersson et al., 2009). From this perspective, we can hypothesize that the business climate indicators might ignite the most significant reaction of the financial market. With respect to U.S. macroeconomic news announcements, NFP and PMI are among the earliest indicators to be published each month. Retail Sales, CPI, Industrial Production and PPI are released in the middle of the month. Core Durable Goods Orders are announced at the end of the month, Trade Balance is released after the month ends, and quarterly GDP is published one month after the respective quarter ends. The first information about the German economy is provided via the business climate indicators (Purchasing Managers Indices, Ifo Business Climate Index, and ZEW Economic Sentiment Index). Later on, CPI, PPI, Retail Sales, Trade Balance, and Industrial Production are available. The last one released is GDP. ${ }^{7}$

\subsection{Monetary settings}

We also analyze the effects of monetary policy decisions. We now provide a brief background of the monetary policy settings in the U.S. and Europe and describe the events we investigate.

In December 2009, with the financial crisis in full swing, the Federal Open Market Committee (FOMC) of the Fed lowered the target for the federal funds rate to nearly zero. The unfamiliar monetary environment of the zero lower bound interest rate policy (ZIRP) lasted until December 2015. Applying the ZIRP is a method of stimulating economic growth, while keeping interest rates close to zero. Under this policy, the governing central bank can no longer reduce interest rates, rendering conventional monetary policy ineffective. As a result, unconventional monetary policy such as quantitative easing is used to increase the monetary

\footnotetext{
${ }^{7}$ A confounding events problem may occur if two or more macroeconomic announcements are released on the same day, within a 90-minute time span, and do not have the same hypothesized effect on the quoting currency. In the U.S., the problem is chiefly connected with CPI, PPI, and Industrial Production. Industrial Production is always released 45 minutes after the price indices. We consider news on CPI, PPI and Industrial Production only if they do not contain contradictory information, i.e., if all the announcements have the same effect on the quoting currency (we follow the approach suggested by Park (2004); further details are provided in Table 1).
} 
base. We analyze the impact of six events when the Fed changed the monetary policy settings during the examined time period.

The main task of the European Central Bank (ECB) is to maintain price stability in the euro area and to preserve the purchasing power of the joint currency. The ECB targets CPI at a rate close to but below two percent. ECB announcements inform investors about decisions on interest rates. Following the U.S. financial crisis and the European debt crisis, the ECB gradually lowered all three main interest rates in the examined time period. We investigate the market reaction to the ECB rate announcements only on the days when at least one of the three main rates were changed. Furthermore, we look into two more ECB meetings. On January 22, 2015 there was no rate change, but the ECB announced the planned launch of the Quantitative Easing (QE) program at a press conference. This event took place after the rate announcement at 2:30 p.m. CET and on March 5, 2015 the ECB introduced details of the QE program.

The list, content, timing, and other details of the monetary policy settings are presented in Table A7 in the Appendix. Because of the varied nature of Fed and ECB events, we quantify these events in the form of dummy variables with precise time identification. Thus, the monetary policy setting dummy reflects key information arising at the market from each central bank. Because the number of such announcements is small, we set the dummy variable to be equal to one for each event and zero otherwise. In this way, we do not distinguish the qualitative nature of central bank announcements. Rather, we aim to capture the potential effect of central bank announcements as well as the recognition of such announcements by the market.

\section{Event Study Methodology Approach}

We analyze the effects of macroeconomic announcements and policy settings on exchange rates using event study methodology (ESM) as outlined in Ball and Brown (1968) and Fama et al. (1969). We opt for the ESM because of its precision in identifying the reaction of an asset following each event. The approach is grounded in the fact that the effect of the macroeconomic announcements is analyzed during periods when news enters the market and avoids extended periods without announcements (Swanson, 2011). Further, in contrast with time-series methods, the ESM allows to focus on examinations of specific events that are isolated from other unwanted news disturbances (noise) that occur outside of the event window (Fatum and Hutchinson, 2003b). Thus, the ESM avoids the problem of "noise" 
affecting the precision of the time-series approach (Fratzscher, 2008). ${ }^{8}$ Further, with the ESM we can test market efficiency as systematically nonzero abnormal security returns that persist after a particular type of event are inconsistent with market efficiency (Busse and Green, 2002). The ESM has been widely employed to analyze forex markets in different regions (Égert, 2007; Browman et al., 2015), with various data frequencies (Poole, 2005; Menkhoff, 2010), including intraday frequency (Ranaldo and Rossi, 2011; Fuentes et al., 2014).

The initial task of conducting an event study is to define the event of interest and to identify the period over which an asset price will be examined, e.g. an event window. In this paper, the assets are currency prices (new-EU-country exchange rates) and the events are defined as the unexpected component of the macroeconomic news announcements and the central bank's monetary policy changes; they are described in detail in the data section. The effect of such events is hypothesized to materialize in abnormal returns that are studied with respect to pre-event and event windows.

\subsection{Pre-event and event windows}

The key element of an event study is the appropriate choice of pre-event and event windows, and typically the estimation window and the event window do not overlap (MacKinlay, 1997). It is customary to define the pre-event window as larger than the event window. We define the windows in the following way. First, similar to Gurgul and Wójtowicz (2014), we set the pre-event window at 130 minutes. That is more than two hours before the event occurs. Second, we choose the event window to have a length of 26 minutes. The event window covers (i) exchange rate returns that occur five minutes before the event, (ii) returns at the time of the news announcement (labeled as the zero-minute period that lasts for one minute) and (iii) returns covering the 20 minutes after the macroeconomic news announcement. ${ }^{9}$ The choice of the event window's length is grounded in the following facts related to each segment of the event window. First, because investors and traders know the calendar of macroeconomic news announcements and form expectations about their values, abnormal returns related to each specific event may also occur in the pre-event period. Thus, the event window starts five minutes before the news announcement. Second, we consider 20 minutes

\footnotetext{
${ }^{8}$ We acknowledge the wealth of research contained in studies examining the impact of macroeconomic news announcements and central bank monetary policy settings via in time-series approach. They employ various types of (G)ARCH models in order to examine jointly the conditional volatility and market reaction. Examples assessing the issue on emerging European financial markets include Egert and Kočenda (2007, 2011, 2014), Buttner et al. (2012), Hanousek et al. (2009), and Hanousek and Kočenda (2011).

${ }^{9}$ When estimating pre-event period parameters, the event period is generally not included. This procedure prevents the event itself from influencing the parameters obtained from the estimation of the normal performance model.
} 
after the news release to be a sufficiently long time for the news to be absorbed by the financial market because Égert and Kočenda (2011) show that new information entering the Czech, Hungarian, and Polish stock markets is largely absorbed by the markets within five minutes after the announcement and it is fully absorbed within 20 minutes. ${ }^{10}$

\subsection{Abnormal returns}

Abnormal returns are defined as the difference between actual returns and their expected values. Hence, for the $i$ th event and time $t$ the abnormal return $\left(\mathrm{AR}_{\mathrm{it}}\right)$ is defined formally as:

$$
A R_{i t}=r_{i t}-E\left[r_{i t} / x_{i t}\right]
$$

where $r_{i t}$ denotes the actual return and $E\left[r_{i t} / x_{i t}\right]$ denotes the expected return, given the conditioning information $x_{i t}$ for the expected return model.

We follow the practice in the literature (MacKinlay, 1997; Kothari and Warner, 2006) and calculate expected returns from a model estimated on the basis of the returns materializing before the event window. ${ }^{11}$ All computations are based on one-minute logreturns computed on the close prices.

When estimating the expected returns $E\left[r_{i t} / x_{i t}\right]$, we test the currencies' returns for autocorrelation and heteroscedasticity over all 155-minute-long periods (pre-event plus event windows) associated with $i$ th event. ${ }^{12}$ As either autocorrelation or heteroscedasticity are largely absent in the returns we employ a Constant Mean Returns Model (CMRM); an autoregressive model would be an alternative in case of detected autocorrelation. Hence, the expected returns are derived based on the following CMRM regression:

$$
E\left[r_{i t} / x_{i t}\right]=\mu_{i}+\xi_{i t}
$$

\footnotetext{
${ }^{10}$ The pre-event window begins at $\mathrm{t}=-135$ minutes and runs up to -6 minutes before the news announcement. The event window evolves from $t=-5$ to +20 , that is from five minutes before the news announcement until 20 minutes after it. The time when the news is released $\left(\mathrm{t}_{0}\right)$ is assigned as 0 .

${ }^{11}$ The same approach has recently been adopted by Shah and Arora (2014) and Gurgul and Wójtowicz (2014).

${ }^{12}$ In appendix Tables A1-A6 we show in the parenthesis the distribution of the examined German/Eurozone and U.S. events (457 and 494 in total, respectively). In appendix Table A7 we show the number of the ECB and FED announcements on monetary policy settings (12 and 6 in total, respectively). We work with 3 new EU currencies denominated in EUR and USD; eg. we analyze 6 exchange rates. Hence, the number of all 155-minute-long periods (pre-event plus event windows) is $2907[=3 *(457+12)+3 *(494+6)]$. Accordingly, we perform the Ljung-Box test on all 2907 series of returns and squared returns. Absence of autocorrelation is shown in 2839 cases out of 2907 tests on returns and in 2868 cases out of 2907 tests on squared returns. Thus, in general, we do not find presence of autocorrelation or heteroskedasticity in returns. The results of these tests occupy substantial space; hence, they are not reported but are available upon request.
} 
where $\mu_{\mathrm{i}}$ is the mean return for asset $i$ and $\xi_{\mathrm{it}}$ is the time period $t$ disturbance term for event $i$ with an expectation of zero $\left(\mathrm{E}\left(\xi_{\mathrm{it}}\right)=0\right)$ and variance $\operatorname{var}\left(\xi_{\mathrm{i}}\right)=\sigma_{\zeta \mathrm{i}}{ }^{2}$. Although the constant mean return model is perhaps the simplest model, Brown and Warner (1985) find that it often yields a result similar to those of more sophisticated models. This logic corresponds to MacKinlay (1997), who argues that the lack of sensitivity to a particular model is due to a very small reduction of the variance of the abnormal returns when a more sophisticated model is employed.

\subsection{Standardized abnormal returns}

In financial markets, volatility of abnormal returns tends to increase at the time of macroeconomic news announcements, i.e. during event window. To effectively account for a change in variance in abnormal returns and to ensure that each abnormal return will have the same variance we proceed with their standardization. We calculate the standardized abnormal returns, to be tested for statistical significance, instead of using the estimated ones (Corrado, 2011; Corrado and Truong, 2008). The standardized abnormal returns $S A R_{i t}$ are defined as the ratio of abnormal returns and standard deviation:

$$
\mathrm{SAR}_{i t}=\mathrm{AR}_{i t} / \mathrm{S}\left(\mathrm{AR}_{i}\right)
$$

where $S\left(A R_{i}\right)$ is the standard deviation of abnormal returns from the pre-event window ( $t$ running from minus 135 to minus six). The standard deviation is calculated in the following way:

$$
S\left(A R_{i}\right)=\sqrt{\frac{1}{129} \sum_{t=-135}^{-6} A R_{i t}^{2}}
$$

Further, the standardized abnormal returns are classified into two categories in order to control for the event-induced volatility change in the cross-sectional variance:

$$
S A R_{i t}^{\prime}= \begin{cases}S A R_{i t} & t=-135, \ldots, 0 \\ S A R_{i t} / S\left(S A R_{t}\right) & t=1, \ldots, 20\end{cases}
$$

where

$$
S(S A R)_{t}=\sqrt{\frac{1}{N-1} \sum_{i=1}^{N}\left(S A R_{i t}-\overline{S A R}_{i t}\right)^{2}} .
$$


$S\left(S A R_{t}\right)$ is the cross-sectional standard deviation of standardized abnormal returns, $\overline{S A R}_{i t}$ is average standardized abnormal return calculated as $\frac{1}{N} \sum_{i=1}^{N} S A R_{i t}$ and $N$ is the number of observations in the cluster.

To test the statistical significance of mean abnormal returns in the event window, we employ the rank test of Corrado and Zivney (1992) with the correction of event-implied volatility by using SAR as described above. The two main advantages of this nonparametric test are that it does not need any assumption about the normality of abnormal returns and compared to other tests used in event studies, it has higher power than other standardized tests (Corrado, 2011). Furthermore, the rank test of Corrado and Zivney (1992) based on the event period standardized returns has proven to be robust both against event-induced volatility (Campbell and Wasley, 1993) and to cross-correlation due to event day clustering (Kolari and Pynnönen, 2010).

The statistical significance of standardized abnormal returns is tested by the CorradoZivney $T_{c z}$ statistics; its calculation is based on the standardized ranks as defined in Corrado (2011):

$$
T_{C Z}\left(t_{0}\right)=\frac{1}{\sqrt{N}} \sum_{i=1}^{N} \frac{\left(\operatorname{rank}\left(S A R_{i t 0}^{\prime}\right)-\frac{n+1}{2}\right)}{\sqrt{n(n+1) / 12}}
$$

where $t_{0}$ stands for each individually examined minute in the event window, $n$ represents the size of the pre-event window (i.e., $\mathrm{n}=130)$. Rank $\left(S A R_{i t 0}^{\prime}\right)$ implies the rank of $S A R_{i t 0}^{\prime}$ within the series of the standardized abnormal returns $\left(S A R_{i t}^{\prime}\right)$ from the pre-event window calculated by the Formula (6). With increasing number of observations $(n)$, the distribution of $T_{c z}$ statistics converges quickly to the standard normal distribution.

The values of abnormal returns during pre-event and post-event windows are assessed in conjunction with their statistical significance and serve as the basis for the interpretation of our results, presented in the next section.

\subsection{Testable hypotheses}

Based on our research topic we formulate the following testable hypotheses.

Hypothesis 1: Macroeconomic news announcements (for German/Eurozone and U.S. economies) do not affect the value of new-EU-country exchange rates. 
Hypothesis 2: There is no difference among types of macroeconomic news announcements with respect to their effect on the value of new EU exchange rates.

Hypothesis 3: The origin of an announcement is irrelevant with respect to its effect on the value of new-EU-country exchange rates.

Hypothesis 4: There is no difference in the qualitative direction of a news announcement (good, bad, or neutral) with respect to the effect on the value of new-EUcountry exchange rates.

Hypothesis 5: There is no difference in the market reaction before and after the news announcement.

Hypothesis 6: The new-EU-country currency market does not exhibit temporary inefficiency related to news announcements. ${ }^{13}$

Hypothesis 7: Announcements about ECB or Fed monetary policy settings do not affect the value of new-EU-country currencies.

Hypothesis 8: There is no difference in qualitative and quantitative market reaction on the news announcements during the EU debt crisis.

\section{Empirical Results}

\subsection{Abnormal returns: effect of the news}

We assess the impact of German/Eurozone macroeconomic news announcements on exchange rates quoted with respect to the euro (CZK/EUR, PLN/EUR, HUF/EUR). Similarly, we assess the effect of U.S. macroeconomic news announcements on exchange rates quoted with respect to the U.S. dollar (CZK/USD, PLN/USD, HUF/USD). The news announcements are divided into three clusters: good, bad, and neutral news, as defined in Section 2.2. ${ }^{14}$ The results are presented in appendix in the Tables A1-A6. The impact of news announcements is characterized by the mean abnormal returns (in percent). Hence, for each macroeconomic

\footnotetext{
${ }^{13}$ Generally, in an efficient market new public information is incorporated very quickly into asset prices. Therefore, the effect of news announcements is visible only for a very short time.

${ }^{14}$ Good news is news with a value above the market consensus, bad news is below the market consensus, and neutral news is in line with the market consensus. This logic applies to all macroeconomic announcements except for CPI and PPI, where good news is below the market consensus (i.e. lower than the expected inflation) and bad news is above the market consensus (i.e. higher than the expected inflation). There are no neutral news for PMI in the case of euro-denominated exchange rates.

As a preliminary exercise, we also analyzed the effect of the news without distinguishing among good, bad and neutral news. We have found that all of the examined macroeconomic announcements are linked to significant abnormal returns over much of the event window. Moreover, the abnormal returns are often present also before the announcements are officially released. The biggest impact, in terms of the highest abnormal return, in eurodenominated currency pairs, occurs on the PMI indices, the Ifo index, and the GDP release. With respect to the U.S. dollar-denominated currency pairs, the highest abnormal returns are linked with the NFP and GDP releases. The exchange rates with respect to the U.S. dollar exhibit higher abnormal returns than the euro-denominated currency pairs. The detailed results are not reported but are available upon request.
} 
news announcement and each minute we report the value of the percentage mean abnormal return $(\mathrm{AR} \%)$ and the corresponding $p$-value. We report the results from -5 up to +10 minutes, covering the period before and after the news release; later on the statistically significant impact of the announcements quickly evaporates. The number of events in each cluster is shown in parentheses, close to each announcement label.

Overall, from the tables we see that the immediate reaction during the first couple of minutes after the news release can be observed in the case of CPI and PPI. The market reaction to the news on prices and their movements is intuitively correct and can also be understood based on the theory. ${ }^{15}$ The longest reaction in terms of significant abnormal returns after the news release can be traced to the announcements of PMI, Retail Sales, Ifo, or Industrial Production. This finding indicates that news from the real economy does have important information value for the market. It also indirectly hints that transactions on the new-EU-country forex markets do reflect real economic activities despite the fact that globally the majority of forex transactions are speculative in nature. ${ }^{16}$

\section{Euro-denominated exchange rates (CZK/EUR, PLN/EUR, HUF/EUR)}

The occurrence of statistically significant abnormal returns right at the time of a news release $(t=0)$ is considerable, albeit not dominant (Tables A1-A3). Rather, the exchange rates react to abnormal returns in the following minutes. The Hungarian forint (HUF/EUR) shows the largest number of statistically significant abnormal returns, which implies a less efficient market (Table A3). The strongest reaction of all of the new-EU-country currencies is exhibited for the ZEW index, the PMI index, the Ifo index, and GDP as the abnormal returns are farther from zero (Tables A1-A3). This finding might be related to the sequence of the release of macroeconomic indicators. Generally, the strongest reaction of the market is identified with neutral news. This may be explained by the fact that this cluster in most cases

\footnotetext{
${ }^{15}$ A movement in prices affects the real interest rate along with terms of trade, and a movement in prices also affects the prices of forex options via interest rate parity. In both cases a movement in prices potentially strongly impacts the amount of money traded on the forex market.

${ }^{16}$ The financial education website Investopedia states that "day-to-day corporate needs comprise only about $20 \%$ of the market volume. Fully $80 \%$ of trades in the currency market are speculative in nature" (http://www.investopedia.com/articles/forex/06/sevenfxfaqs.asp; retrieved on March 10, 2016). The data provided by the BIS (2013; p.6) do not provide a direct estimate of speculative trading but allow an indirect inference via foreign exchange market turnover by counterparty that is proportionally divided among nonfinancial customers (9\%), reporting dealers (39\%), and other financial institutions (53\%). Further, in terms of instruments, "FX swaps were the most actively traded instruments in April 2013, at $\$ 2.2$ trillion per day, followed by spot trading at $\$ 2.0$ trillion" (BIS, 2013; p.3).
} 
contains a small number of events. ${ }^{17}$ The highest significant abnormal return appears in HUF/EUR three minutes after a good German GDP data release (Table A3). ZEW, PMI, and Ifo are the first indices giving us new information about the economy. Bad news about industrial production is related to the longest statistically significant reaction for all new-EUcountry currencies. With respect to the euro-denominated exchange rates, we can observe three key patterns (Tables A1-A3): (i) the values of abnormal returns are smaller, (ii) the number of statistically significant abnormal returns is lower than with U.S. dollardenominated exchange rates, and (iii) the statistically significant abnormal returns in the case of euro-denominated exchange rates appear immediately after the news announcements. We also see that larger abnormal returns are in general linked more with good news than with bad news; this is consistent with the graphical presentation in Figure 4. In the case of bad news, there are significant abnormal returns even before the announcement of PMI, Retail Sales, and Trade Balance significant for CZK/EUR and HUF/EUR. Based on the results presented in Tables A1-A3 we can reject null Hypothesis 5 as we firmly document that there is a difference in the market reaction before and after the news announcement. These preannouncement price drifts are important evidence that news does leak or are even traded before their official release. This behavior is not uncommon and has been found in many other studies. For example, Lucca and Moench (2015) confirm, that since 1994 international equities react largely and with high statistical significance before official FOMC announcements are released. Further, Kurov et al. (2017) show that prices of stock indices and future prices of treasuries start to move in line with the direction of the news announcement about 30 minutes before the release time.

\section{U.S. dollar-denominated exchange rates}

In the case of the U.S. dollar-denominated exchange rates, three key patterns emerge (Tables A4-A6). First, the values of abnormal returns are larger. Second, statistically significant abnormal returns occur more often than in the case of euro-denominated exchange rates. Therefore, the results show that the segment of the new-EU-country forex market where currencies are traded with respect to the U.S. dollar exhibits more temporary inefficiencies than its euro-based counterpart. The results are also consistent with the graphical

\footnotetext{
${ }^{17}$ The fact that neutral news is often linked to quite high abnormal returns might indicate that analysts, whose expectations form the market consensus, are understandably not always successful in predicting macroeconomic indicators with a complete accuracy. This can be explained by the wide range of possible outcomes of individual macroeconomic indicators. Some indicators are subject to less outcome possibilities and, for example, it is more probable to estimate the correct prediction for CPI than for NFP. The explanation is credited to an anonymous referee.
} 
representation in Figure 4. Third, statistically significant abnormal returns occur much later, usually two minutes after an announcement is released.

Some specific results further underline the above common patterns. The strongest reaction in terms of abnormal returns is related to NFP and GDP announcements. Again, NFP is one of the first news released at the beginning of each month, while GDP is a comprehensive number representing the state of the whole economy. NFP news is possibly leaked as the highest significant abnormal return emerges one minute before the (good) NFP announcement is actually released. ${ }^{18}$ As a contrast to the above, announcements of Industrial Production and Core Durable Goods Orders exhibit the weakest reaction in terms of the low values of the associated abnormal returns.

Finally, one minute before the news announcement there is a strong statistically significant reaction of all U.S. dollar-denominated exchange rates to the good news of the NFP, PMI Services index, Retail Sales, and Core Durable Goods Orders (Tables A4-A6). The U.S. dollar-denominated exchange rates exhibit the smallest amount of statistically significant returns following the announcements of Industrial Production, CPI, PPI, and Trade Balance. Based on the above evidence, we can reject null Hypothesis 1 because there is ample evidence that macroeconomic news announcements affect abnormal returns. Further, we can also reject the null Hypothesis 2 as specific macroeconomic news announcements exhibit different effects on the value of new-EU-country exchange rates.

\subsection{Size of abnormal returns}

The impact of the announcements presented in Tables A1-A6 indicates the presence of asymmetric reactions. We verify this feature and establish its statistical background. First, we present the Box-and-Whisker plots of the percentage mean abnormal returns (AR\%) in Figure 3. The plots show the distribution asymmetry of mean abnormal returns related to the three clusters of macroeconomic news announcements, i.e. good, bad, and neutral. The abnormal returns in the neutral cluster show the biggest dispersion. This may be explained either by the low number of observations in the cluster or by the indecisiveness of investors whether neutral news is actually positive or negative for the quoting currency. The mean abnormal returns of the new-EU-country exchange rates denominated in USD reach higher absolute values than those denominated in the euro. As a result, we may say that the forex segment

\footnotetext{
${ }^{18}$ We consider only good and bad news clusters because there is a low number of observations of neutral news.
} 
with new-EU-country exchange rates denominated in the U.S. dollar is less efficient than that with new-EU-country currencies denominated in euro.

We further perform a nonparametric Kruskal-Wallis (KW) test to statistically establish the evidence of the above asymmetry. Specifically, we compare the reaction of new EU foreign exchange rates after the individual news announcements classified into appropriate clusters of good, bad, or neutral news during the first minute after the news announcement and alternatively also during the first five minutes in order to account for the cumulative market reaction. The results show that in the case of euro-denominated exchange rates abnormal returns react significantly differently to good news from the ZEW index (one minute) and Retail Sales (one and five minutes), to bad news from the ZEW index (five minutes) and Ifo index (one minute), and to neutral news on the CPI (one and five minutes). For the U.S. dollar-denominated exchange rates the results show no asymmetry in the distribution of abnormal returns for any type of news. To summarize, only euro-denominated exchange rates react differently to some announcements and Hypothesis 4 of equal distribution may be rejected. The detailed results are not reported but are available upon request.

\subsection{Duration of abnormal returns}

An examination of post-event returns provides us with information on market efficiency. Systematically nonzero abnormal returns following an event are inconsistent with market efficiency and imply a profitable trading rule (ignoring trading costs). Therefore, the speed of market adjustment to the information revealed at the time of the event is an empirical question. We test the market efficiency hypothesis by applying the cumulative average residual method (CAR). CAR uses the sum of each minute's average abnormal returns in percent (AR\%). CAR starting at time $t_{1}$ through time $t_{2}$ (event window) is defined as:

$$
\operatorname{CAR}\left(\mathrm{t}_{1}, \mathrm{t}_{2}\right)=\sum_{t=\mathrm{t} 1}^{\mathrm{t} 2} A R t
$$

where $t_{1}$ is equal to -5 ( 5 minutes before the news release) and $t_{2}$ equals 20 (the last minute of the event window).

The aggregation of mean abnormal returns through time provides us with information about the overall influence of the event of interest on the new-EU-country currency market. Moreover, CAR describes the duration and strength of each news cluster (good, bad, or neutral) on euro- or U.S. dollar-denominated new-EU-country currencies in the first 20 
minutes after the news announcement, as well as shortly before news is actually released (Figure 4). The left and right portions of Figure 4 depict CAR for euro- and U.S. dollardenominated exchange rates, respectively. ${ }^{19}$

A visual inspection of Figure 4 shows a substantial effect of macroeconomic announcements on new-EU-country currencies. However, important asymmetries can be detected with respect to both base currencies. Good German/Eurozone macroeconomic news leads to new EU (quoting) currency appreciation with respect to the euro (base currency). This does not mean that the euro depreciates after good news is released. Rather, the CAR evidences a stronger reaction of the new-EU-country currencies to good news from Germany/the Eurozone. Similarly, neutral news that is in line with market consensus leads to new-EU-country (quoting) currency appreciation as well. In a sense, we might say that the finding resonates well with the common notion that "no news is good news". On the contrary, bad news leads towards a depreciation of the new-EU-country currencies with respect to the euro.

The U.S. dollar-denominated exchange rates offer a different picture, though. Good U.S. macroeconomic news leads to U.S. dollar (base currency) appreciation and local newEU-country (quoting) currency depreciation; the opposite pattern is linked to bad news. This discrepancy in the reaction, when compared to the euro-denominated exchange rates, can be reasonably explained, though. Earlier we stressed the importance of economic links between the new EU countries and the Eurozone and specifically Germany. Hence, there is a strong reaction of the new-EU-country currencies to German/Eurozone news. On the other hand, the economic links of the new EU countries with the U.S. are less strong. Hence, when U.S.originated good news is released, both the U.S. dollar and other currencies react. It is no surprise that the reaction of the U.S. dollar should be stronger than the reaction of any newEU-country currency. Therefore, a depreciation of a new-EU-country currency following good U.S. news simply means that the reaction of the currency is weaker than the reaction of the U.S. dollar itself. The reaction to neutral news is mixed. Finally, note that the reaction of U.S. dollar-denominated exchange rates is greater than reaction of those linked to the euro. This is clearly visible as the scales of the two parts of Figure 4 are not the same.

\footnotetext{
${ }^{19}$ As we defined earlier in Section 2.1, a negative change (growth rate) in an exchange rate means an appreciation of the quoting currency (CZK, HUF, PLN) with respect to the reference currency (EUR, USD). In terms of the monetary profit realized by a forex trader, appreciation means a positive return because less units of the quoting currency is needed to buy 1 unit of the reference currency. Same analogy is valid for a currency's depreciation. We graphically present positive (negative) cumulative abnormal returns (CAR) in a positive (negative) domain of the graph.
} 
The CAR analysis provides an aggregate assessment and shows the pattern of the market reaction. The cumulative abnormal returns of the euro-denominated exchange rates reach lower values with a maximum of $0.2 \%$ and a minimum of $-0.2 \%$ during the first 20 minutes after the news release, while those linked to the U.S. dollar reach three times higher values with a maximum slightly above $0.9 \%$ and a minimum slightly below $0 . \%$. This means that the overall impact of macroeconomic news announcements is stronger for the U.S. pairs than the euro pairs. The above results allow us to reject null Hypothesis 3. Hence, there are considerable differences in the size of the news effect on the value of the new-EU-country currencies with respect to the origin of the news. The above results also mean that the forex market's segment with new-EU-country currencies denominated in the U.S. dollar is less efficient than that with currencies related to the euro.

The reaction of U.S.-denominated new-EU-country currencies to bad news is 50 percent stronger than the reaction to good news. The CARs of U.S. dollar-denominated newEU exchange rates reach $0.9 \%$ after bad news and $-0 . \%$ following good news. Moreover, the reaction of the market to bad news lasts longer. It takes twice as long for the CAR curve to get flat. Conversely, euro-denominated new-EU-country currencies show a heavier reaction to good news when it comes to CZK/EUR and PLN/EUR. This does not hold for HUF/EUR, where CAR for bad news reaches higher values than for good news, especially from the 11th minute after the news announcement. Null Hypothesis 4 about new-EU-country currencies' equal reaction to all types of news (good, bad, and neutral) is rejected.

Concerning the duration of the news announcement effect, it is obvious that mean abnormal returns appear on the market even before the news is released. Generally speaking, CAR starts to move two minutes before the announcement. The strong immediate market reaction takes place two minutes after the announcement for good news and approximately five minutes after for bad news. This does not hold for PLN/EUR, which reacts indifferently to bad news. Following the results above and in Figure 4 we can see that new public information is relatively quickly incorporated into the currency prices, despite that some temporary inefficiencies exist. In this respect, we can reject null Hypothesis 6 that the newEU-country forex market does not exhibit temporary inefficiency. On the other hand, based on our results the new EU forex markets seem to be quite efficient in general.

\subsection{ECB and Fed communication on their monetary policy settings}

Finally, we examine the reaction of new-EU-country currencies to changes in the Eurozone and U.S. monetary policy settings. We analyze these reactions during the period (2011-2015) 
characterized by the fact that conventional monetary policy tools were unable to adequately respond to the economic situation (Swanson and Williams, 2014). Many central banks had to find new ways of using the tools at their disposal to stimulate economic activity in the face of the prolonged downturn and sluggish recovery. One way of doing so was, and for many central banks continues to be, further asset purchases on the central bank's account with the policy interest rate already at (or near) the zero bound.

We examine the forex market reaction when the ECB or the Fed announced changes in their monetary policy settings mostly related to monetary expansion (see Table A7 in the Appendix for details). The quantitative results are shown in Table 2: all three currencies react to steps taken by the two key central banks in a remarkably different manner.

The Czech koruna reacted immediately after the ECB loosened monetary policy conditions. The CZK/EUR exchange rate exhibits the strongest reaction among the eurodenominated exchange rates as the abnormal returns are statistically significant immediately after the news release. The forceful and quick reaction of CZK/EUR is, however, complicated with alternating signs of abnormal returns. Such an undetermined direction of movement may be explained by the CNB currency interventions and its presence on the currency market as, on the stronger side of the CZK 27/EUR level, the CNB is preventing the koruna from further appreciation by intervening on the foreign exchange market. Mean abnormal returns of $\mathrm{PLN} / \mathrm{CZK}$ is mostly consistent in the direction of the currency reaction, even though significant abnormal returns appear only five minutes after information release. The result shows that easier monetary conditions in the Eurozone led to the depreciation of the Polish currency and euro appreciation. The reaction of HUF/EUR is the mildest one.

The impact of U.S. monetary policy changes on the new-EU-country currencies is present but is less significant than that of the ECB monetary policy. ${ }^{20}$ Both PLN/USD and HUF/USD depreciate after the Fed eases monetary policy. Negative abnormal returns appear in the first minute after the news release and depreciation reaches $0.024 \%$ (PLN) and $0.49 \%$ (HUF). There is no statistically significant impact on CZK/USD, though.

\footnotetext{
${ }^{20}$ We acknowledge that the more significant impact of ECB monetary policy settings in comparison with Fed statements might be also due to the timing of when reports are published. ECB reports are published at 1:45 pm CET (7:45 am EST) followed by a press conference at 2:30 pm CET (8:30 am EST). This means that the ECB policy reports are published during the period of highest market activity, when UK and U.S. forex trading sessions overlap. Conversely, the Fed's statements are always published at 2:00 pm EST (8:00 pm CET) followed by a press conference at 2:30 pm EST (8:30 pm CET), i.e., during the U.S. trading session when many traders in Europe are no longer active in the markets. On the other hand, 24-hour trading on the forex market does allow for the policy announcements to affect exchange rates around the clock.
} 
Based on the above findings we can reject null Hypothesis 7 because we provide evidence that ECB and Fed monetary policy changes do affect short-term changes in the value of new-EU currencies.

\subsection{Impact of the European sovereign debt crisis}

The sample period considered in our empirical study covers a post-U.S. financial crisis period but it also involves the European sovereign debt crisis period. In this section we explore the impact of the EU debt crisis on the new EU currency pairs during the interval January 1, 2011-July 26, 2012. ${ }^{21}$

Draghi (2014) clearly distinguishes timing of both crises, plus shows the differences in the relationship between financial stress and unemployment during the financial crisis (from 2008) and debt crisis (from 2011). Hence, we begin the analysis of the debt crisis interval in early 2011 "because during this period, the sovereign debt crisis erupted in full force" as argued by Frutos et al. (2016; p. 17) who, in their analysis of the stress on the euro-area interbank market, also show a progressing divergence of the government bonds' yield within the euro-area. The end of the debt crisis interval coincides with the remarkable verbatim of the ECB President Mario Draghi who, at the Global Investment Conference in London on July 26, 2012, said: "Within our mandate, the ECB is ready to do whatever it takes to preserve the euro. And believe me, it will be enough" (Draghi, 2012). Fiordelisi and Ricci (2016) show that the European financial markets started to rally immediately after the above statement and economic situation begun to improve as well. ${ }^{22}$

We assess the issue of the European sovereign debt crisis based on the cumulative abnormal returns (CAR) shown separately for the debt crisis (Figure 5) and post-debt crisis (Figure 6) periods. The dynamics of the post-debt crisis period's CAR is remarkably similar to that reported already for the full span of our analysis (Figure 4). However, the dynamics of the debt-crisis CAR (Figure 5) differs for the CAR of the U.S. dollar denominated exchange rate returns. The debt-crisis CAR patterns for the U.S. dollar-denominated exchange rates (Figure 5) indicate that during the European sovereign debt crisis the new-EU markets reacted quite sensitively to the positive U.S. macro news. Such sensitivity might be strengthened by the fact that the three new EU countries were to some extent protected from the negative impact of the euro-area debt-crisis by having their own currencies. Further, during the

\footnotetext{
${ }^{21} \mathrm{We}$ are grateful to anonymous referee for bringing this issue to our attention. The Section 4.5 is the result.

${ }^{22}$ Eurostoxx gained $4.3 \%$ on the day of the speech $(8.1 \%$ up to the end of July 2012); other important stock indices performed in a similar way: IBEX 6.1\% (13.1\%), S\&PMIB 5.6\% (12.4\%), CAC40 4.1\% (7.1\%), DAX $2.8 \%(6.0 \%)$.
} 
European sovereign debt crisis the U.S. economic situation was better compared to that in the EU (McKee et al., 2012). Hence, despite the dominating connection of the new EU countries to the EU and the euro-area, the positive U.S. announcements were received by the new EU forex markets remarkably well. In sum, the debt-crisis CAR patterns for the U.S. dollardenominated exchange rates (Figure 5) indicate that during the European sovereign debt crisis the new-EU markets reacted quite sensitively to positive macro news. In this respect, positive U.S. macroeconomic data have been conveying the sign of restored economic growth in the U.S. and signaled some potential of the economy recovery coming to the euro-area as well. Hence, the contrast between the positive news coming from the U.S. and bleak economic prospects during the European sovereign debt crisis seems to be a realistic factor behind the finding.

Our interpretation can be further corroborated by the findings of Baruník et al. (2017) who, in their intra-day analysis, show that negative volatility spillovers among the key world currencies during 2011-2012 were chiefly tied to the sovereign debt crisis in Europe. In addition, when comparing the CAR values during the sovereign debt crisis and post-crisis periods, we observe that the market segment with the euro-denominated exchange rates is more efficient in post-crisis period. The situation is different in the market segment with the U.S. dollar-denominated exchange rates that becomes less efficient after the European debt crisis in terms of high CAR values. Finally, the set of the above findings allows us to reject Hypothesis 8.

\section{Conclusions}

In this paper, we analyze the impact of specific information entering the forex market on the currencies of new EU members (Czech koruna, Hungarian forint, and Polish zloty); the exchange rates are denominated in the euro and the U.S. dollar. The information covered includes Eurozone/Germany and U.S. macroeconomic news announcements, and communication on the monetary policy settings of the ECB and the Fed. In our analysis, we fully exploit the wealth of intraday data and cover a relatively long period after the global financial crisis (2011-2015). As a tool, we use event study methodology (ESM) because of its precision in identifying the reaction of an asset following each event, i.e. a macroeconomic announcement or policy setting communication. The impact of the events is characterized by the behavior of the mean abnormal returns. Hence, by using ESM we are also able to assess temporary forex market inefficiencies. 
The results of our analysis can be summarized as follows. The biggest impact, in terms of the highest abnormal return, in euro-denominated currency pairs, occurs on PMI indices, the Ifo index, and the GDP release. With respect to the U.S. dollar-denominated currency pairs, the highest abnormal returns are linked with the NFP and GDP releases. The longest reaction in terms of significant abnormal returns after the news release can be traced to announcements of the PMI, Retail Sales, Ifo, or Industrial Production. The exchange rates with respect to the U.S. dollar exhibit higher abnormal returns than euro-denominated currency pairs.

We distinguish the surprise element in the announcements by dividing the news into three clusters - good, bad, and neutral news - which are defined by the difference between the announcement and its expectation. Larger abnormal returns after Eurozone/Germany news announcements are in general linked with good news. Conversely, in the case of U.S. dollardenominated exchange rates, larger abnormal returns are linked to bad news. The results also show that the values of statistically significant abnormal returns of the euro-denominated exchange rates are smaller, occur less often, and last for a shorter time than for U.S. dollardenominated exchange rates. Finally, the segment of the new EU forex market, where currencies are traded with respect to the euro, is more efficient than its U.S. dollar-based counterpart. Examining the EU debt crisis separately, we noticed that the dynamics of the debt-crisis CAR differs for the U.S. dollar denominated exchange rate returns during the European debt crisis. Particularly, positive U.S. announcements result in positive CAR. Sharp difference in the economic development between the U.S. and the euro-area during the debt crisis seem to be a plausible factor behind the result.

Communications on the monetary policy settings show that ECB communication matters. The CZK/EUR exchange rate exhibits the strongest and HUF/EUR the quietest reaction among euro-denominated exchange rates. The impact of Fed monetary policy changes on the new-EU-country currencies is present but less significant than that of the ECB: both PLN/USD and HUF/USD depreciate after the Fed eases monetary policy but there is no statistically significant impact on the CZK/USD exchange rate.

Our analysis is the first of its kind, providing a comprehensive analysis of the reaction of selected new EU forex markets to a wide array of macroeconomic information during the post-GFC period. We show strong and specific reactions along with temporary inefficiencies present on these forex markets. 


\section{References}

Andersen, T. G., Bollerslev, T., Diebold, F. X., Vega, C. (2003). Micro Effects of Macro Announcements: Real-Time Price Discovery in Foreign Exchange. American Economic Review, 93(1), 38-62.

Andersen, T. G., Bollerslev, T., Diebold, F. X., Vega, C. (2007). Real-time price discovery in global stock, bond and Foreign Exchange markets. Journal of International Economics, 73(2), 251-277.

Andersson, M., Overby, L. J., Sebestyén, S. (2009). Which News Moves the Euro Area Bond Market? German Economic Review, 10(02), 1-31.

Andritzky, J. R., Bannister, G. J., Tamirisa, N. T. (2007). The Impact of Macroeconomic Announcements on Emerging Market Bonds. Emerging Markets Review, 8(1), 20-37.

Ball, R., Brown, P. (1968). An Empirical Evaluation of Accounting Income Numbers. Journal of Accounting Research, 6(2), 159-78.

Baruník, J., Kočenda, E., Vácha, L. (2017). Asymmetric Volatility Connectedness on the Forex Market. Journal of International Money and Finance, 77, 39-56.

BIS (2013). Triennial central bank survey. Foreign exchange turnover in April 2013: preliminary global results. Technical report, Monetary and Economic Department, Bank for International Settlements.

Bredin, D., Hyde, S. J., O'Reilly, G. P. (2009). European monetary policy surprises: the aggregate and sectoral stock market response. International Journal of Finance \& Economics, 14(2), 156-171.

Bowman, D., Londono, J.M., Sapriza, H. (2015). U.S. unconventional monetary policy and transmission to emerging market economies. Journal of International Money and Finance, vol. 55(C), 27-59.

Brown, S. J., Warner, J. B. (1980). Measuring security price performance. Journal of Financial Economics, 8(3), 205-258.

Busse, A., Green, T.C. (2002). Market efficiency in real time. Journal of Financial Economics, 65(3), 415-437.

Büttner, D., Hayo, B., Neuenkirch, M. (2012). The impact of foreign macroeconomic news on financial markets in the Czech Republic, Hungary, and Poland. Empirica, 39(1), 1944.

Cai, F., Joo, H., Zhang, Z. (2009). The Impact of Macroeconomic Announcements on Real Time Foreign Exchange Rates in Emerging Markets. International Finance Discussion Papers, no. 973. Board of Governors of the Federal Reserve System (U.S.).

Cakan, E., Doytch, N., Upadhyaya, K.P. (2015). Does U.S. macroeconomic news make emerging financial markets riskier? Borsa Istanbul Review, 15(1), 37-43.

Campbell, C., Wasley, C. (1993). Measuring Security Price Performance Using Daily NASDAQ Returns. Journal of Financial Economics, 33(1), 73-92.

Caporale, G.M., Spagnolo, F., Spagnolo, N. (2017). Macro news and exchange rates in the BRICS. Finance Research Letters 21, 140-143.

Cavusoglu, N. (2011). Exchange rates and the effectiveness of actual and oral interventions: A survey on findings, issues and policy implications. Global Economy Journal, 10(4), $1-40$.

Chaboud, A. P., Chernenko, S. V., Howorka, E., Iyer, R. S. K., Liu, D., Wright, J. H. (2004). The High-Frequency Effects of U.S. Macroeconomic Data Releases on Prices and Trading Activity in the Global Interdealer Foreign Exchange Market. Board of Governors of the Federal Reserve System, International Finance DP No. 823.

Corrado, C. J. (2011). Event studies: A methodology review. Accounting and Finance, 51(1), 207-234. 
Corrado, C. J., Truong, C. (2008). Conducting event studies with Asia-Pacific security market data. Pacific-Basin Finance Journal, 16(5), 493-521.

Corrado, C. J., Zivney, T. L. (1992). The specification and power of the sign test in event study hypothesis tests using daily stock returns. Journal of Financial and Quantitative Analysis, 27(03), 465-478.

Draghi, M. (2012). Verbatim of the remarks made by Mario Draghi. Speech by Mario Draghi, President of the European Central Bank at the Global Investment Conference in London, 26 July 2012. Available at: https://www.ecb.europa.eu/press/key/date/2012/html/sp120726.en.html (Accessed on July 26, 2017).

Draghi, M. (2014). Unemployment in the euro area. Speech by Mario Draghi, President of the ECB, Annual central bank symposium in Jackson Hole, 22 August 2014. Available at: https://www.ecb.europa.eu/press/key/date/2014/html/sp140822.en.html (Accessed on July 26, 2017).

Egert, B. (2007). Central bank interventions, communication and interest rate policy in emerging European economies. Journal of Comparative Economics, 35(2), 387-413.

Egert, B., Kočenda, E. (2007). Interdependence between Eastern and Western European Stock Markets: Evidence from Intraday Data. Economic Systems, 31(2), 184-203.

Egert, B., Kočenda, E. (2011). Time-Varying Synchronization of the European Stock Markets. Empirical Economics, 40(2), 393-407.

Egert, B., Kočenda, E. (2014). The impact of macro news and central bank communication on emerging European forex markets. Economic Systems, 38(1), 73-88.

Ehrmann, M., Fratzscher, M. (2005). Equal size, equal role? Interdependence between the euro area and the United States. The Economic Journal, 115(506), 928-948.

Fama, E. F., Fisher, L., Jensen, M. C., Roll, R. (1969). The Adjustment of Stock Prices to New Information. International Economic Review, 10(1), 1-21.

Fatum, Rasmus and Hutchison, Michael M. Is Sterilised Foreign Exchange Intervention Effective After All? An event study Approach. The Economic Journal, April 2003b, 113(487), 390-411.

Faust, J., Rogers, J. H., Swanson, E., Wright, J. H. (2003). Identifying the Effects of Monetary Policy Shocks on Exchange Rates Using High Frequency Data. Journal of the European Economic Association, 1(5), 1031-1057.

Fedorova, E., Wallenius, L., Collan, M., (2014). The Impact of Euro Area Macroeconomic Announcements on CIVETS Stock Markets. Procedia Economics and Finance, vol. 15, 27-37.

Fiordelisi, F., Ricci, O. (2016). "Whatever it takes": An Empirical Assessment of the Value of Policy Actions in Banking. Review of Finance, 20(6), 2321-2347.

Fratzscher, M. (2006). On the long-term effectiveness of exchange rate communication and interventions. Journal of International Money and Finance, 25(1), 146-167.

Fratzscher, M. (2008). Oral Interventions Versus Actual Interventions in Fx Markets - An Event-Study Approach. The Economic Journal, 118(530), 1079-1106.

Frutos, J.C., Garcia-de-Andoain, C., Heider, F., Papsdorf, P. (2016). Stressed interbank markets: evidence from the European financial and sovereign debt crisis. European Central Bank WP No. 1925.

Fuentes, M., Pincheira, P., Julio, J.M., Rincón, H., García-Verdú, S., Zerecero, M., Vega, M., Lahura, E., Moreno, R. (2014). The effects of intraday foreign exchange market operations in Latin America: results for Chile, Colombia, Mexico and Peru. BIS Working Papers No. 462. 
Gilbert, T., Scotti, Ch., Strasser, G., Vega, C. (2016). Is the intrinsic value of macroeconomic news announcements related to their asset price impact? ECB Working Paper No. 1882.

Gurgul, H., Wójtowicz, T. (2014). The impact of US macroeconomic news on the Polish stock market. Central European Journal of Operations Research, 22(4), 795-817.

Gürkaynak, R. S., Sack, B., Swanson, E. (2005). Do Actions Speak Louder Than Words? The Response of Asset Prices to Monetary Policy Actions and Statements. International Journal of Central Banking, 1(1), 55-93.

Hanousek, J., Kočenda, E. (2011). Foreign News and Spillovers in Emerging European Stock Markets. Review of International Economics, 19(1), 170-188.

Hanousek, J., Kočenda, E., Kutan, A. (2009). The Reaction of Asset Prices to Macroeconomic Announcements in New EU Markets: Evidence from Intraday Data. Journal of Financial Stability, 5(2), 199-219.

Hayo, B., Kutan, A. M., Neuenkirch, M. (2010). The impact of U.S. central bank communication on European and pacific equity markets. Economics Letters, 108(2), 172-174.

Jotikasthira, C., Lundblad, C., Ramadorai, T. (2012). Asset Fire Sales and Purchases and the International Transmission of Funding Shocks. Journal of Finance, 67(6), 2015-2050.

Kolari, J. W., Pynnönen, S. (2010). Event study testing with cross-sectional correlation of abnormal returns. Review of Financial Studies, 23(11), 3996-4025.

Kothari, S. P., Warner, J. B. (2006). Econometrics of Event Studies. In Eckbo, B.E. (Ed.), Handbook of Corporate Finance: Empirical Corporate Finance, Elsevier/NorthHolland, vol. 1, Ch. 1.

Kurov, A., Sancetta, A., Strasser, G., Wolfe, M.H. (2017). Price drift before U.S. macroeconomic news: private information about public announcements? Forthcoming in Journal of Financial and Quantitative Analysis.

Laakkonen, H. (2007). Exchange Rate Volatility, Macro Announcements and Choice of the Intraday Seasonality Filtering Method. Bank of Finland Research DP No. 23/2007.

Leon, H., Williams, O. H. (2012). Effectiveness of intervention in a small emerging market: an event study approach. Applied Financial Economics, 22(21), 1811-1820

Lucca, D.O., Moench, E. (2015). The Pre-FOMC Announcement Drift. The Journal of Finance, 70(1), 329-371.

MacKinlay, A. C. (1997). Event studies in economics and finance. Journal of Economic Literature, 35(1), 13-39.

McKee, M., Karanikolos, M., Belcher, P., Stuckler, D. (2012). Austerity: a failed experiment on the people of Europe. Clinical Medicine, 12(4), 346-350.

Menkhoff, L. (2010). High-frequency analysis of foreign exchange interventions: What do we learn? Journal of Economic Surveys. 24(1), 85-112.

Menkhoff, L. (2013). Foreign Exchange Intervention in Emerging Markets: A Survey of Empirical Studies. The World Economy, 36(9), 1187-1208.

Naidu, A. S. H. (2011). Effectiveness of Foreign Exchange Market Intervention in India: An Event Study Analysis. Institute of Public Enterprise. Journal of Economic Policy \& Research, 6(2).

Neely, CJ., Dey, S.R. (2010). A Survey of Announcement Effects on Foreign Exchange Returns. Federal Reserve Bank of St. Louis Review, 92(5), 417-463.

Orlowski, L.T., 2012. Financial crisis and extreme market risks: Evidence from Europe. Review of Financial Economics, 21(3), 120-130.

Orlowski, L.T., 2016. Co-movements of non-Euro EU currencies with the Euro. International Review of Economics \& Finance, 45(C), 376-383. 
Park, N.K. (2004). A guide to using event study methods in multi-country settings. Strategic Management Journal, 25, 655-668.

Poole, W. (2005). How predictable is Fed policy? Federal Reserve Bank of St. Louis Review, 87(6), 659-68.

Rai, V., Suchanek, L. (2014). The Effect of the Federal Reserve's Tapering Announcements on Emerging Markets. Bank of Canada Working Paper, No. 2014-50.

Ramchander, S., Simpson, M. W., Thiewes, H., (2008). The Effects of Macroeconomic News on German Closed-End Funds. Quarterly Review of Economics and Finance, 48(4), 708-724.

Ranaldo, A., Rossi, E. (2010). The reaction of asset markets to Swiss National Bank communication. Journal of International Money and Finance, 29(3), 486-503.

Savor, P., Wilson, M. (2013). How Much Do Investors Care About Macroeconomic Risk? Evidence from Scheduled Economic Announcements. Journal of Financial and Quantitative Analysis, 48(2), 343-375.

Scalia, A. (2008). Is foreign exchange intervention effective? Some microanalytical evidence from the Czech Republic. Journal of International Money and Finance, 27(4), 529546.

Shah, P., Arora, P. (2014). M\&A Announcements and Their Effect on Return to Shareholders: An Event Study. Accounting and Finance Research, 3(2), 170-190.

Swanson, E. T. (2011). Let's Twist Again: A High-Frequency Event-study Analysis of Operation Twist and Its Implications for QE2. Brookings Papers on Economic Activity, 42 (1), 151-207.

Swanson, E.T., Williams, J.C.,(2014). Measuring the Effect of the Zero Lower Bound on Medium- and Longer-Term Interest Rates. American Economic Review, 104(10): 3154-3185.

Wang, J., Bilson, J. (2017). An Empirical Investigation of Eastern European Bond Markets, Emerging Markets Finance and Trade, 53(1), 199-212.

Wongswan, J. (2009). The response of global equity indexes to U.S. monetary policy announcements. Journal of International Money and Finance, 28(2), 344-365. 
Table 1: German/Eurozone and U.S.A macroeconomic news release calendar

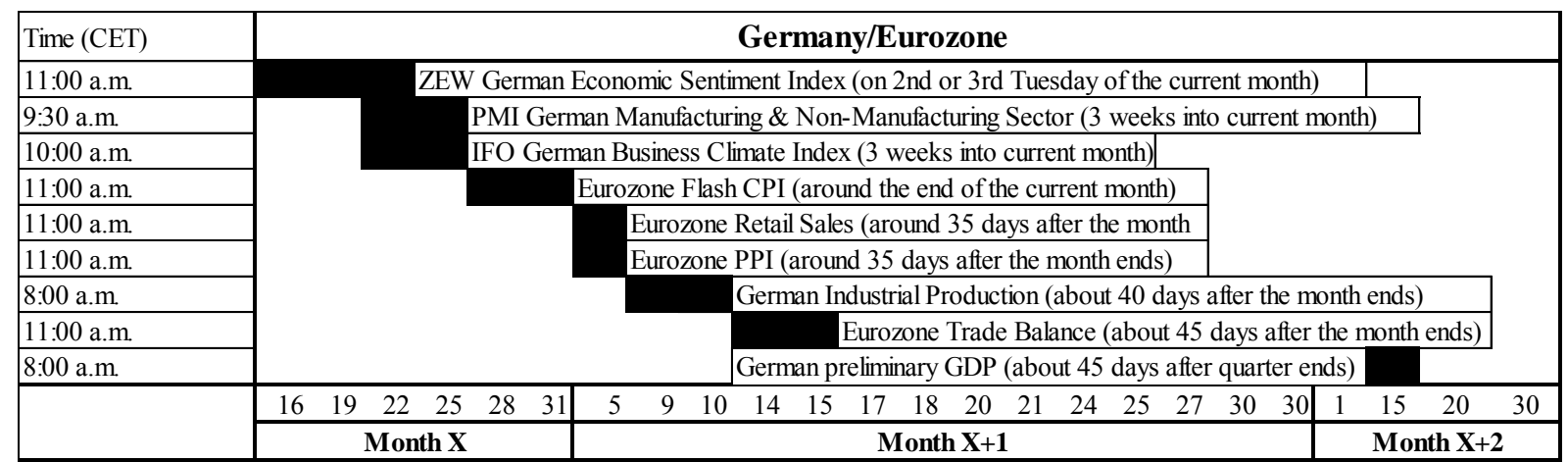

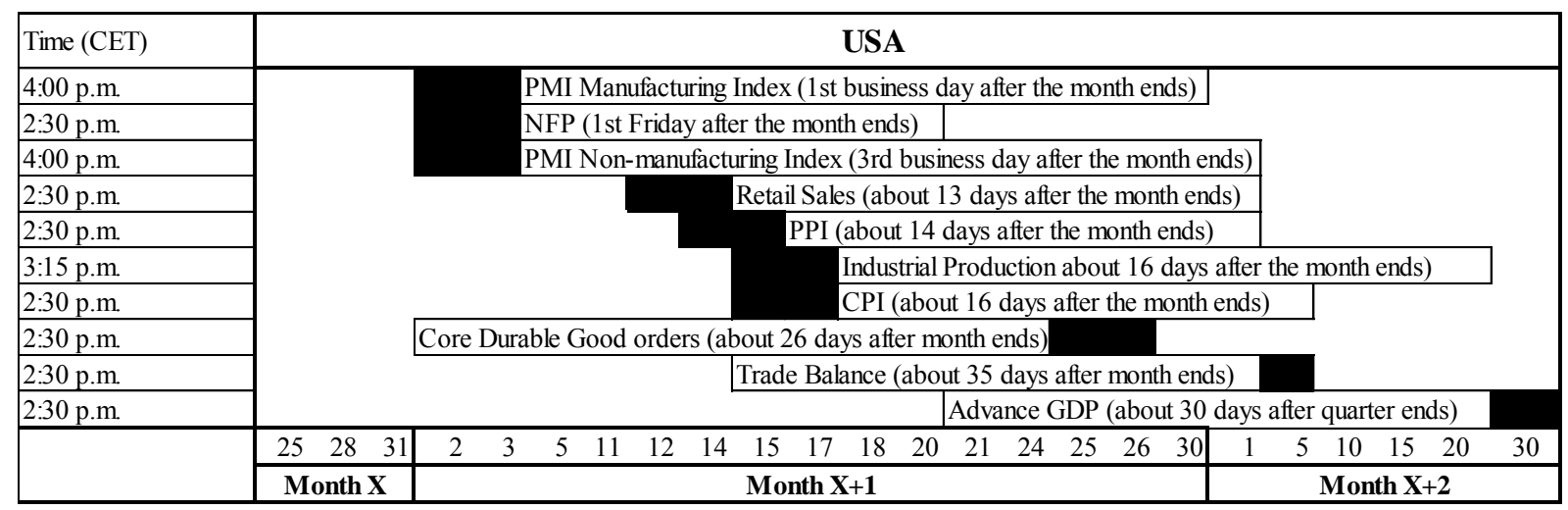

Notes: The table shows the sequence of examined macroeconomic news announcements in Germany/Eurozone and the U.S.A. The time difference between the European and U.S. financial markets is accounted for by setting a homogenous CET time for all news releases so there is no time difference. We took into consideration that Daylight Savings Time starts in the U.S.A. two weeks earlier than in Europe in the spring and ends one week later in the fall. All announcements are released monthly, except for GDP, which is measured quarterly.

The announcements are abbreviated as follows: NFP - Nonfarm Payrolls, PMI - Purchasing Managers' Indices from Manufacturing and Non-Manufacturing (Serv. - Service) Sectors, GDP - Gross Domestic Product, Ind. Prod. - Industrial Production, Core DGO - Core Durable Goods Orders, Trade. Bal. - Trade Balance, CPI - Consumer Price Index, PPI - Producer Price Index, ZEW - German Economic Sentiment Index, IFO - German Business Climate Index, Ret. Sales - Retail Sales.

A confounding events problem may occur if two or more macroeconomic announcements are released on the same day, within a 90-minute time span, and do not have the same hypothesized effect on the quoting currency. In the U.S., the problem is chiefly connected with CPI, PPI, and Industrial Production. Industrial Production is always released 45 minutes after the price indices. We consider news on CPI, PPI and Industrial Production only if they do not contain contradictory information, i.e., if all the announcements have the same effect on the quoting currency. Altogether, there are only 39 of 60 price announcements examined (CPI and PPI). Regarding German PMI indices, we analyze 32 out of 60 events, because PMI indices from the manufacturing and non-manufacturing sectors are usually released on the same date and hour. 
Table 2: Effect of Monetary Policy on Abnormal Returns

Panel A: Effect of the ECB Monetary Policy on Abnormal Returns

\begin{tabular}{|c|c|c|c|c|c|c|c|c|c|}
\hline \multirow{2}{*}{$\stackrel{\Xi}{\xi}$} & \multicolumn{3}{|c|}{ CZK/EUR (12) } & \multicolumn{3}{|c|}{ PLN/EUR (12) } & \multicolumn{3}{|c|}{ HUF/EUR (12) } \\
\hline & AR $\%$ & & Tcz Q & AR \% & & Tcz Q & AR \% & & Tcz Q \\
\hline-5 & 0,000 & c & 1,69 & 0,020 & & $-0,56$ & 0,003 & $\mathrm{a}$ & 3,49 \\
\hline-4 & 0,003 & a & 3,56 & $-0,002$ & b & 2,05 & 0,001 & & 1,09 \\
\hline-3 & 0,006 & & 0,64 & 0,005 & & 0,18 & 0,003 & & 0,20 \\
\hline-2 & $-0,002$ & & 0,56 & $-0,016$ & a & 3,18 & $-0,005$ & & 1,39 \\
\hline-1 & $-0,005$ & c & 1,89 & 0,013 & & 0,37 & 0,005 & c & 1,91 \\
\hline 0 & 0,021 & & $-0,57$ & 0,007 & & $-0,20$ & 0,016 & & $-1,46$ \\
\hline 1 & 0,000 & a & 2,77 & 0,042 & & $-1,00$ & 0,007 & & 0,47 \\
\hline 2 & 0,007 & b & 2,30 & 0,025 & & $-3,00$ & 0,005 & & $-0,21$ \\
\hline 3 & $-0,018$ & $a$ & 2,66 & 0,027 & & $-0,13$ & 0,024 & & $-1,76$ \\
\hline 4 & $-0,001$ & b & 2,08 & $-0,009$ & & 1,53 & 0,000 & & $-0,08$ \\
\hline 5 & 0,005 & & 0,95 & $-0,012$ & $a$ & 3,54 & 0,018 & & 0,80 \\
\hline 6 & 0,001 & $\mathrm{a}$ & 2,77 & 0,005 & & 0,17 & 0,001 & & 0,61 \\
\hline 7 & 0,011 & & 0,38 & $-0,003$ & C & 1,65 & $-0,008$ & & 1,34 \\
\hline 8 & 0,019 & & $-0,02$ & $-0,004$ & b & 2,51 & 0,000 & & 0,86 \\
\hline 9 & 0,011 & & 1,40 & 0,002 & & 0,90 & 0,024 & & $-0,71$ \\
\hline 10 & 0,011 & $b$ & 2,15 & 0,024 & & $-1,77$ & 0,004 & & 0,91 \\
\hline 11 & $-0,003$ & c & 1,66 & $-0,007$ & $b$ & 2,44 & 0,004 & & $-0,46$ \\
\hline 12 & 0,021 & & 0,37 & $-0,006$ & & 1,09 & 0,027 & & $-0,51$ \\
\hline 13 & $-0,005$ & & 1,43 & 0,025 & & $-0,45$ & 0,005 & & 0,20 \\
\hline 14 & 0,008 & & 1,33 & $-0,007$ & & 1,44 & $-0,010$ & $\mathrm{a}$ & 3,33 \\
\hline 15 & $-0,007$ & $a$ & 2,74 & $-0,008$ & $a$ & 2,71 & 0,004 & & $-0,14$ \\
\hline
\end{tabular}

Note: Symbols a, b, and c denote statistical significance at the 1, 5, and $10 \%$ levels based on the Corrado-Zivney $\mathrm{T}_{\mathrm{cz}}$ statistics. 
Panel B: Effect of the Fed Monetary Policy on Abnormal Returns

\begin{tabular}{|c|c|c|c|c|c|c|c|c|}
\hline \multirow{2}{*}{$\stackrel{\stackrel{\Xi}{\xi}}{\underline{F}}$} & \multicolumn{2}{|c|}{ CZK/USD (6) } & \multicolumn{3}{|c|}{ PLN/USD (6) } & \multicolumn{3}{|c|}{ HUF/USD (6) } \\
\hline & AR \% & Tcz Q & AR \% & & Tcz Q & AR \% & & Tcz Q \\
\hline-5 & 0,002 & 1,11 & $-0,001$ & & 0,08 & $-0,015$ & a & 2,94 \\
\hline-4 & 0,002 & 0,86 & 0,009 & & $-0,83$ & 0,001 & & 0,18 \\
\hline-3 & $-0,010$ & 1,54 & 0,002 & & 0,55 & 0,009 & & 0,03 \\
\hline-2 & $-0,032$ & 1,47 & $-0,019$ & & 1,19 & $-0,002$ & & 1,15 \\
\hline-1 & $-0,002$ & 1,21 & $-0,064$ & & 1,58 & $-0,076$ & a & 3,16 \\
\hline 0 & $-0,013$ & 0,51 & $-0,024$ & c & 1,70 & $-0,049$ & b & 2,19 \\
\hline 1 & $-0,045$ & 1,61 & 0,010 & & $-0,15$ & 0,015 & & $-0,12$ \\
\hline 2 & 0,018 & $-0,36$ & 0,002 & & 0,76 & 0,020 & & 0,12 \\
\hline 3 & 0,004 & 0,54 & 0,000 & & 0,98 & 0,020 & & $-0,82$ \\
\hline 4 & 0,010 & $-0,29$ & 0,027 & & $-0,85$ & $-0,007$ & c & 1,67 \\
\hline 5 & $-0,021$ & 0,86 & 0,000 & & $-0,03$ & 0,024 & & 0,08 \\
\hline 6 & 0,002 & 0,88 & 0,031 & & 0,05 & 0,005 & & 0,52 \\
\hline 7 & 0,004 & 0,88 & 0,027 & & $-0,30$ & $-0,005$ & & $-0,03$ \\
\hline 8 & 0,073 & 0,02 & 0,020 & & 0,03 & 0,013 & & 0,38 \\
\hline 9 & 0,015 & $-0,12$ & $-0,039$ & $\mathrm{a}$ & 2,64 & 0,017 & & 0,22 \\
\hline 10 & 0,008 & 0,31 & 0,027 & & 0,59 & $-0,008$ & & 1,32 \\
\hline 11 & 0,039 & $-0,04$ & 0,046 & & $-0,36$ & 0,040 & & $-0,25$ \\
\hline 12 & 0,001 & 1,15 & $-0,005$ & c & 1,71 & 0,023 & & $-0,88$ \\
\hline 13 & $-0,014$ & 1,31 & 0,001 & & 0,69 & $-0,019$ & b & 2,36 \\
\hline 14 & $-0,018$ & 0,98 & 0,005 & & 0,26 & $-0,008$ & & 0,61 \\
\hline
\end{tabular}

Note: Symbols a, b, and c denote statistical significance at the 1, 5, and 10\% levels based on the Corrado-Zivney $\mathrm{T}_{\mathrm{cz}}$ statistics. 
Figure 1: One-minute spot exchange rates of local currencies denominated in Euro (left) and their percentage returns (right).

(January 3, 2011 - December 31, 2015)
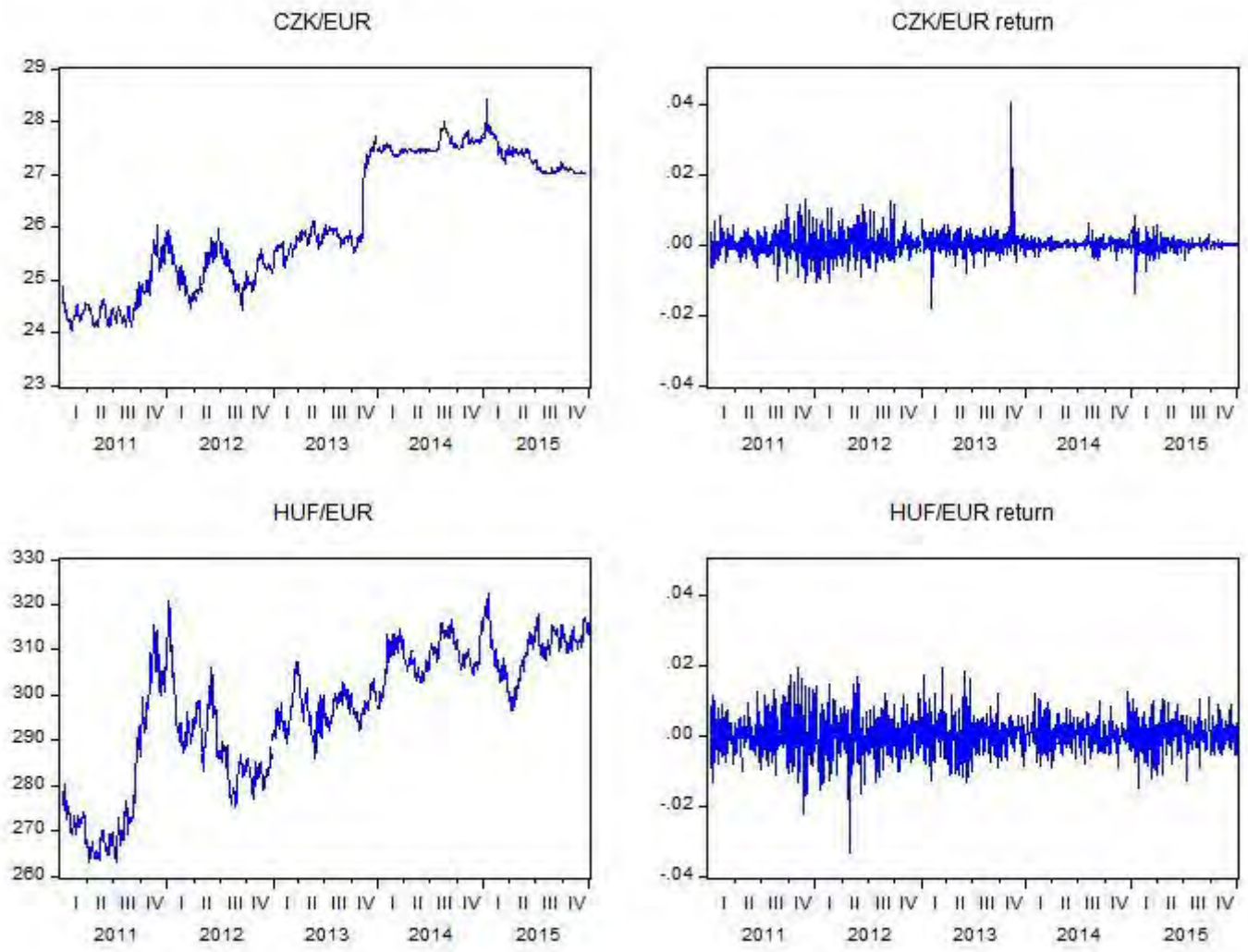

PLN/EUR
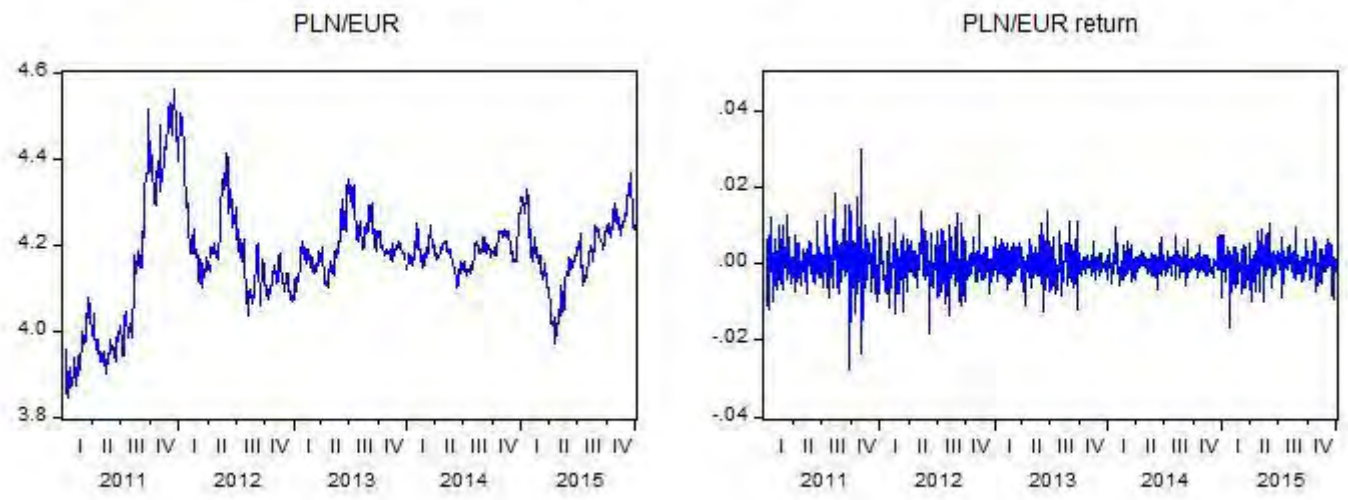
Figure 2: One-minute spot exchange rates of local currencies denominated in U.S. dollar (left) and their percentage returns (right).

(January 3, 2011 - December 31, 2015)

CZKJUSD

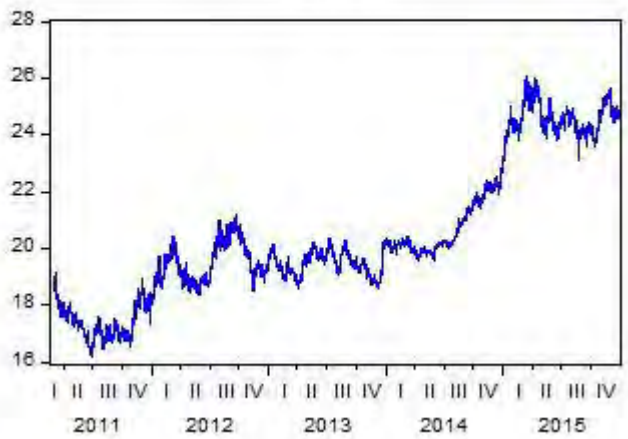

HUF/USD

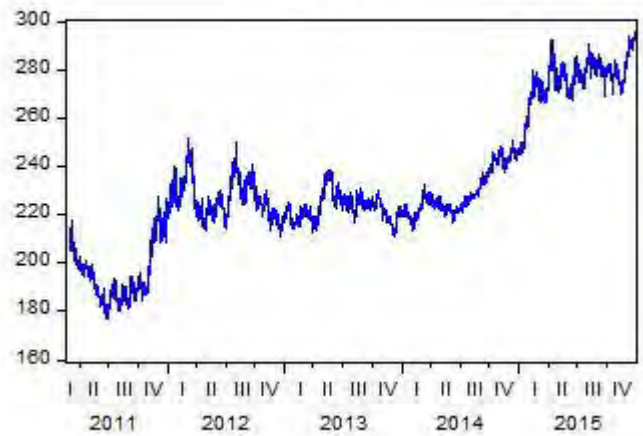

PLN/USD

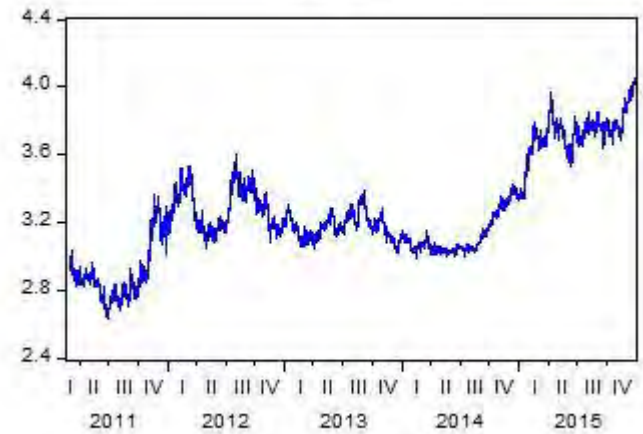

CZKJUSD return

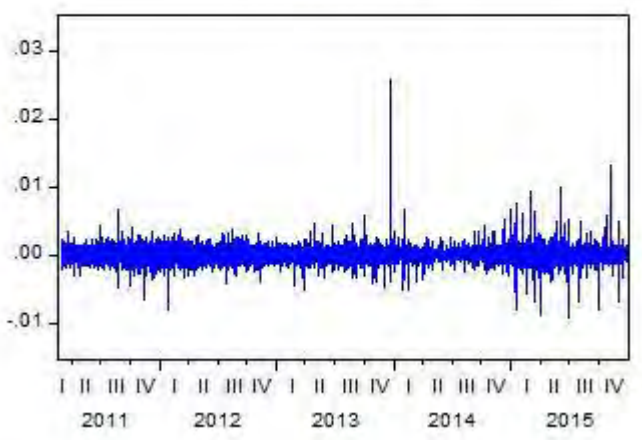

HUF/USD return

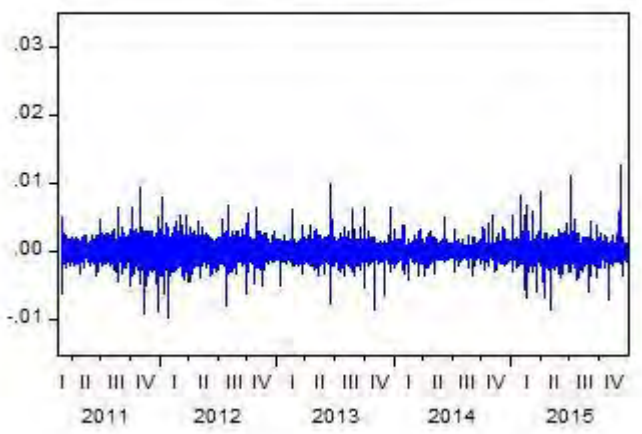

PLN/USD return

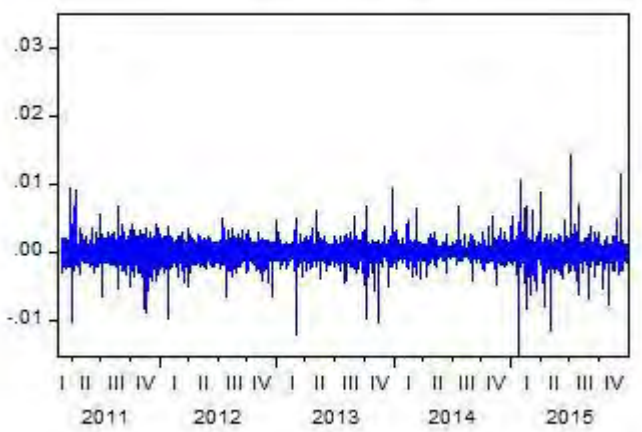


Figure 3: Box-and-whisker plots of percentage abnormal returns (AR\%) linked to clusters of good, bad, and neutral news

Panel A: Exchange rates of local currencies denominated in Euro

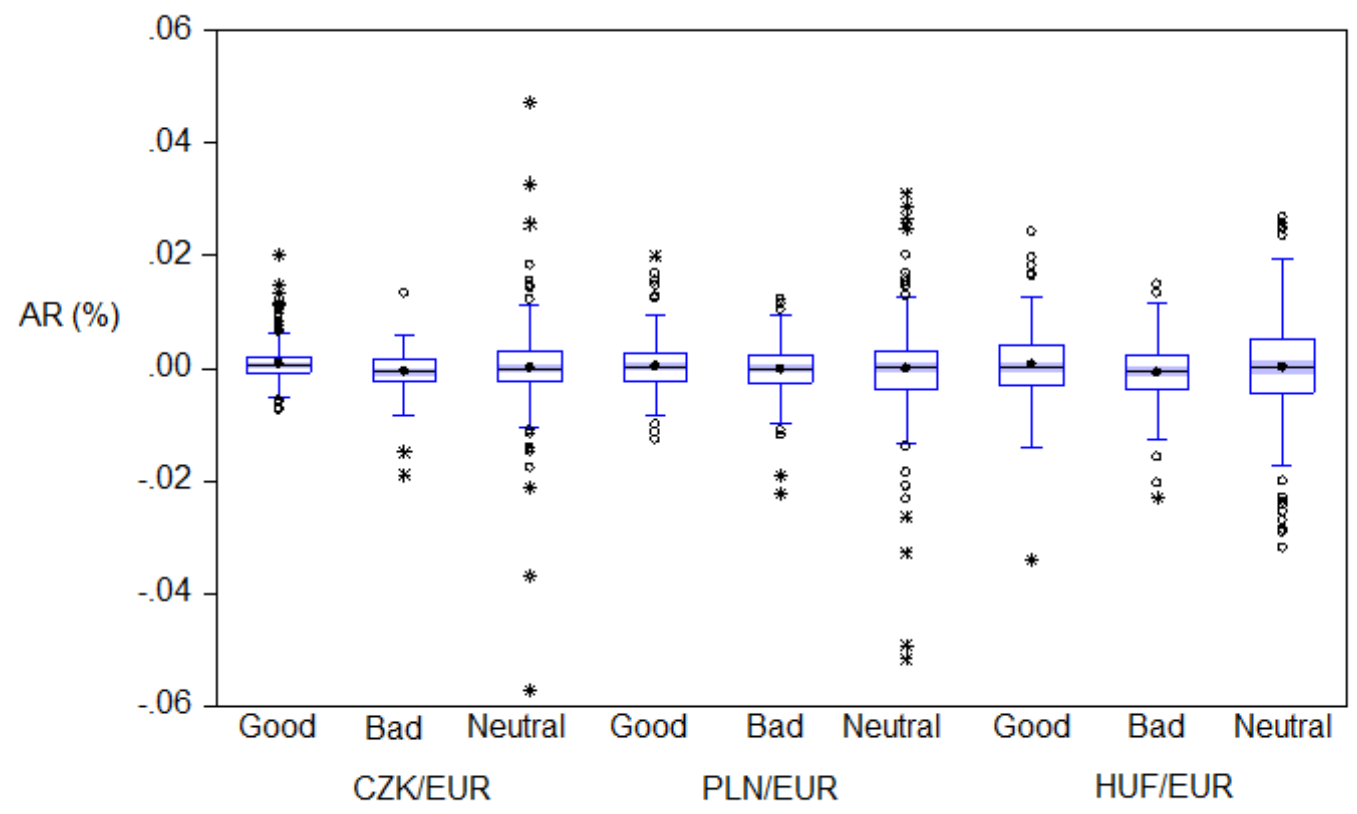

Panel B: Exchange rates of local currencies denominated in U.S. dollar

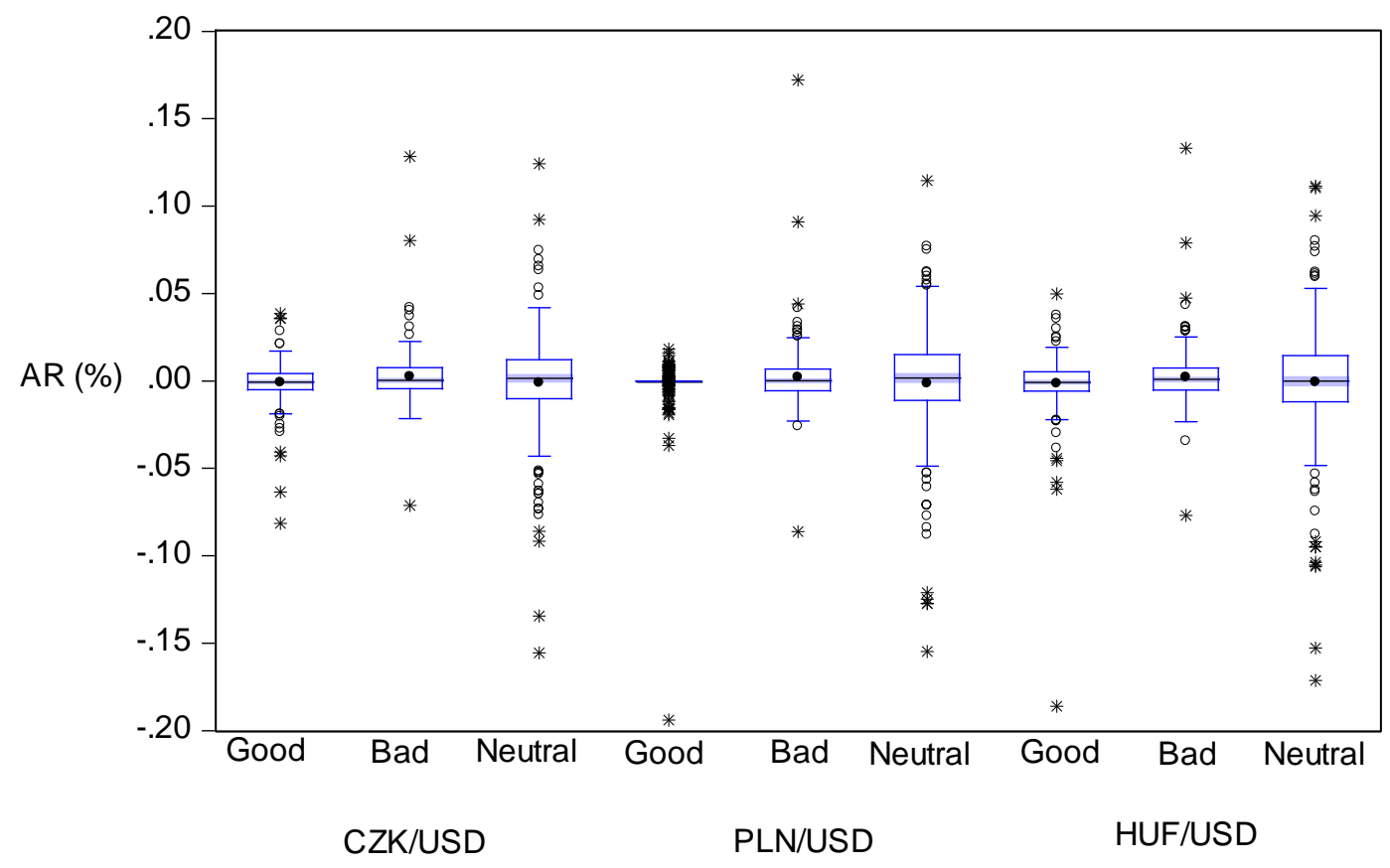


Figure 4: Cumulative mean abnormal returns (CAR in \%) on the currency pairs linked to good, bad, and neutral news

Total examined period (2011-2015)

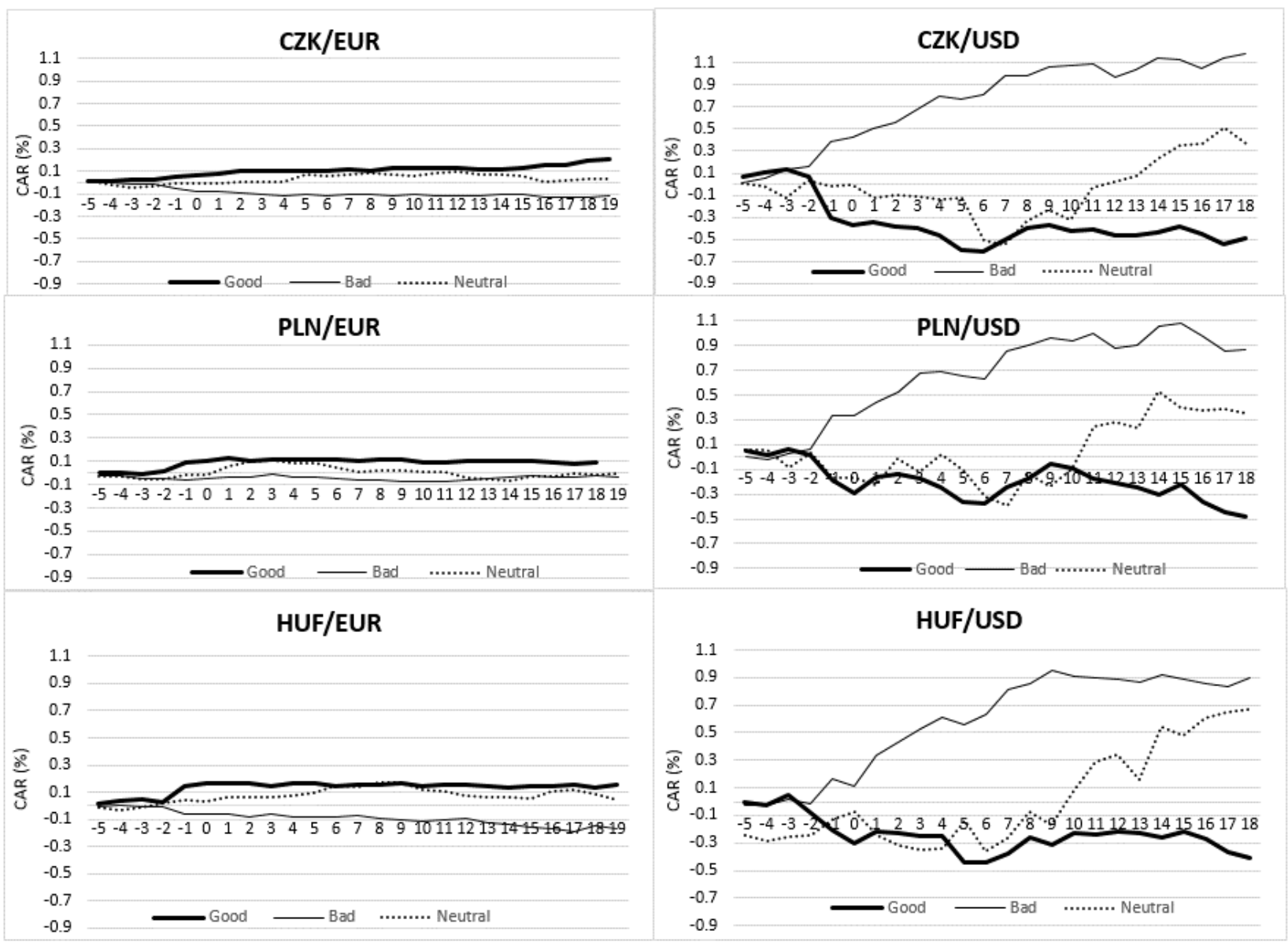


Figure 5: Cumulative mean abnormal returns (CAR in \%) on the currency pairs linked to good, bad, and neutral news

EU debt crisis (3.1.2011- 26.7.2012)
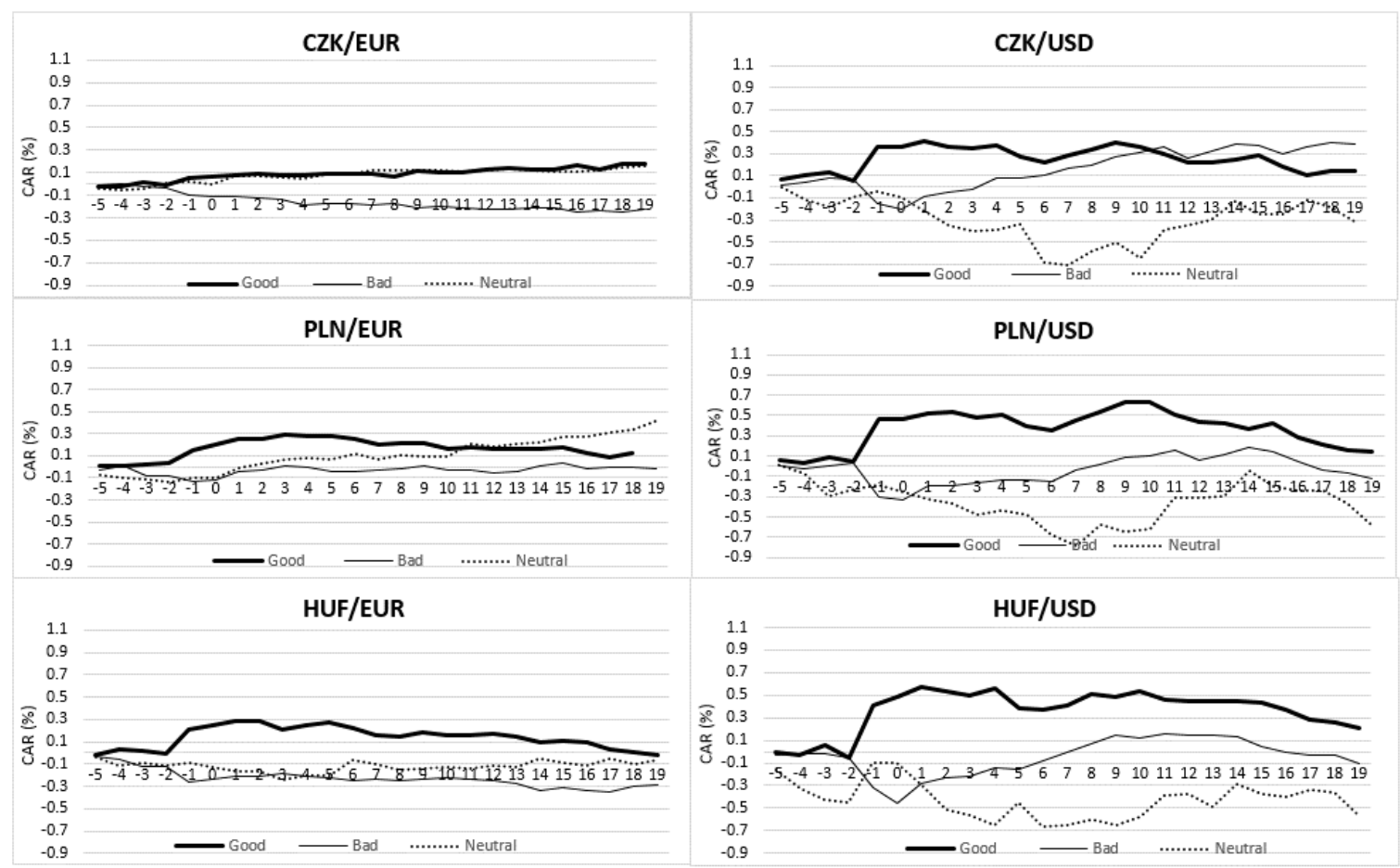

Figure 6: Cumulative mean abnormal returns (CAR in \%) on the currency pairs linked to good, bad, and neutral news

Post-EU debt crisis (27.7.2012 - 31.12.2015)
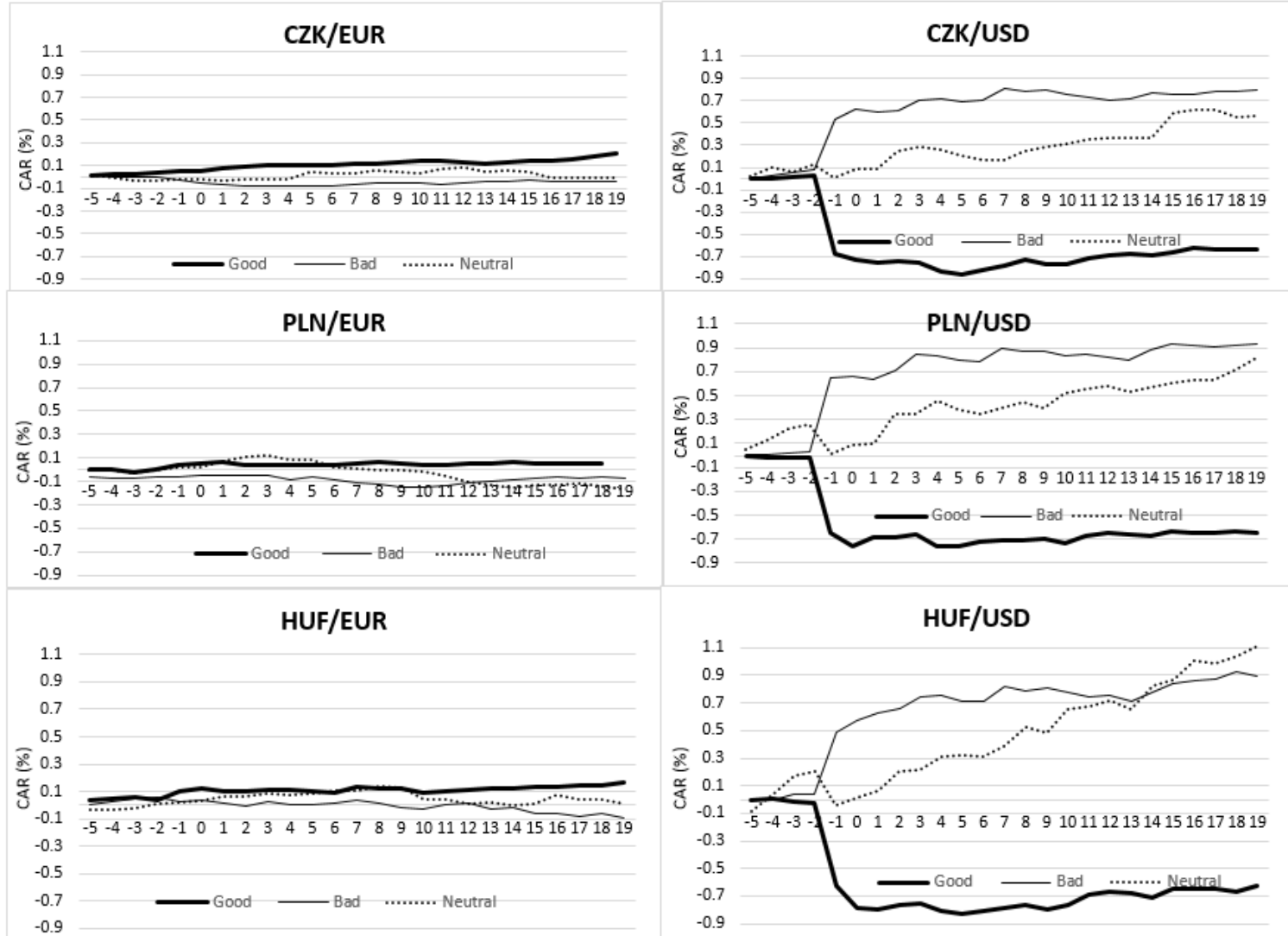


\section{Appendix}

Table A1: Effect of Macroeconomic Announcements on Abnormal Returns of CZK/EUR

A: Good News

\begin{tabular}{|c|c|c|c|c|c|c|c|c|c|c|c|c|c|c|c|c|c|c|}
\hline \multirow{2}{*}{$\stackrel{\stackrel{0}{\xi}}{\underline{E}}$} & \multicolumn{2}{|c|}{ ZEW (24) } & \multicolumn{2}{|c|}{ PMI (13) } & \multicolumn{2}{|l|}{ IFO (31) } & \multicolumn{2}{|c|}{$\begin{array}{l}\text { Ind. Prod. } \\
\text { (24) }\end{array}$} & \multicolumn{2}{|l|}{ GDP (9) } & \multicolumn{2}{|c|}{\begin{tabular}{|c|} 
Retail Sales \\
(23)
\end{tabular}} & \multicolumn{2}{|c|}{\begin{tabular}{|c|} 
Trade \\
Balance (23)
\end{tabular}} & \multicolumn{2}{|l|}{ CPI (21) } & \multicolumn{2}{|c|}{ PPI (24) } \\
\hline & AR \% & & AR \% & & AR \% & & AR \% & & AR \% & & AR \% & & AR \% & & AR \% & & AR \% & \\
\hline-5 & -0.002 & $a$ & 0.009 & $c$ & 0.002 & & .003 & & 0.001 & & -0.001 & & .000 & & 0.000 & & 0.001 & \\
\hline-4 & 0.001 & & & & & & & & 0.000 & & .004 & & 0.002 & & \begin{tabular}{l|l}
0.002 \\
\end{tabular} & & & \\
\hline-3 & & & & & & & & & & & & & & & & & & \\
\hline-2 & & & & & & & & & & $\mathrm{~h}$ & & & & & & & & \\
\hline-1 & 0.0 & & & & & & & & 0.0 & & & & & c & & b & & \\
\hline 0 & 0.000 & $\mathrm{~b}$ & 0.000 & & 4 & $\mathrm{~b}$ & 2 & & 0.002 & & 0.004 & & & $\mathrm{~b}$ & 0.000 & & & \\
\hline 1 & & & & & & & & & & $a$ & & & & $\mathrm{a}$ & & & & \\
\hline 2 & & & & & & & & & & & & & & & & & & \\
\hline 3 & & $a$ & & & & & & & & D & & & & & & & & \\
\hline 4 & -0.002 & & 00 & - & 0.008 & & 3 & a & -0.003 & $a$ & 0.006 & & 0.001 & $\mathrm{~b}$ & \begin{tabular}{|l|}
-0.005 \\
\end{tabular} & & & \\
\hline 5 & 0.001 & a & & & 0.005 & & & & & & -0.003 & & & $h$ & & & & \\
\hline 6 & & & & & & & & & & & & & & & & & & \\
\hline 7 & & - & & & & & & & & & & & & & & & & \\
\hline 8 & -0.0 & & & & & & 4 & $\mathrm{~b}$ & -0.6 & $a$ & 0.002 & & -0.006 & $a$ & 0.001 & & & \\
\hline 9 & 0.004 & & 0.000 & & 0.003 & & \begin{tabular}{l|l}
0.002 \\
\end{tabular} & & -0.001 & $\mathrm{~b}$ & 0.002 & & 0.008 & & 0.000 & & & \\
\hline 10 & -0.001 & & 0.005 & & 0.005 & 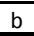 & $\begin{array}{l}0.000 \\
\end{array}$ & $d$ & -0.006 & & 0.001 & & 0.000 & & \begin{tabular}{l|l}
0.001 \\
\end{tabular} & & $\begin{array}{c}0.001 \\
\end{array}$ & \\
\hline
\end{tabular}

B: Bad News

\begin{tabular}{|c|c|c|c|c|c|c|c|c|c|c|c|c|c|c|c|c|c|c|}
\hline \multirow{2}{*}{$\stackrel{\stackrel{g}{\xi}}{\underline{F}}$} & \multicolumn{2}{|c|}{ ZEW (32) } & \multicolumn{2}{|c|}{ PMI (19) } & \multicolumn{2}{|c|}{ IFO (26) } & \multicolumn{2}{|c|}{$\begin{array}{c}\text { Ind. Prod. } \\
\text { (33) }\end{array}$} & \multicolumn{2}{|l|}{ GDP (7) } & \multicolumn{2}{|c|}{$\begin{array}{l}\text { Retail Sales } \\
\text { (29) }\end{array}$} & \multicolumn{2}{|c|}{$\begin{array}{c}\text { Trade } \\
\text { Balance }(30)\end{array}$} & \multicolumn{2}{|c|}{ CPI (21) } & \multicolumn{2}{|c|}{ PPI (24) } \\
\hline & AR \% & & AR \% & & AR \% & & AR\% & & AR \% & & AR \% & & AR \% & & AR \% & & AR \% & \\
\hline-5 & 0.002 & & 0.001 & $b$ & 0.003 & & -0.002 & c & |0.003 & & -0.001 & & -0.001 & & 0.000 & $\mathrm{~b}$ & 0.001 & \\
\hline-4 & 0.003 & & \begin{tabular}{|l|}
-0.002 \\
\end{tabular} & C & 0.000 & $a$ & -0.002 & $a$ & \begin{tabular}{|c|}
-0.007 \\
\end{tabular} & $a$ & 0.000 & c & 0.004 & $b$ & 0.002 & & 0.002 & c \\
\hline-3 & -0.004 & $a$ & -0.005 & $b$ & -0.003 & $a$ & 0.002 & & 0.001 & & 0.003 & & -0.001 & $b$ & 0.000 & & 0.000 & 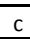 \\
\hline-2 & 0.001 & & -0.004 & $a$ & 0.001 & & -0.001 & $b$ & 0.006 & & -0.003 & $a$ & 0.001 & $\mathrm{~b}$ & -0.001 & 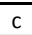 & 0.003 & $\mathrm{~b}$ \\
\hline-1 & -0.007 & $a$ & \begin{tabular}{|l|}
-0.002 \\
\end{tabular} & $b$ & -0.002 & $\mathrm{c}$ & -0.004 & $a$ & \begin{tabular}{|l|}
-0.015 \\
\end{tabular} & $a$ & \begin{tabular}{|l|}
-0.002 \\
\end{tabular} & $a$ & -0.002 & $b$ & 0.000 & $\mathrm{~b}$ & -0.001 & $\mathrm{c}$ \\
\hline 0 & -0.001 & & \begin{tabular}{|l|}
-0.019 \\
\end{tabular} & $a$ & -0.001 & $a$ & -0.002 & $\mathrm{c}$ & \begin{tabular}{|l|}
-0.006 \\
\end{tabular} & $\mathrm{c}$ & 0.001 & & 0.002 & $\mathrm{c}$ & 0.000 & $\mathrm{~b}$ & 0.000 & $b$ \\
\hline 1 & 0.002 & & 0.004 & & 0.000 & $\mathrm{c}$ & -0.002 & $a$ & \begin{tabular}{|l|}
-0.005 \\
\end{tabular} & $\mathrm{~b}$ & 0.000 & $\mathrm{a}$ & -0.005 & $\mathrm{c}$ & -0.002 & 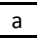 & 0.004 & \\
\hline 2 & 0.000 & & -0.006 & a & 0.000 & c & -0.001 & $a$ & $\begin{array}{l}0.002 \\
\end{array}$ & $\mathrm{~b}$ & 0.003 & & -0.005 & & 0.001 & & 0.000 & \\
\hline 3 & -0.004 & a & -0.005 & $a$ & 0.006 & & -0.002 & $a$ & -0.006 & & 0.004 & & -0.002 & $\mathrm{~b}$ & 0.001 & & -0.005 & $a$ \\
\hline 4 & -0.001 & & -0.003 & $b$ & -0.001 & $b$ & 0.000 & $a$ & \begin{tabular}{|c|}
-0.004 \\
\end{tabular} & & 0.002 & & -0.001 & $a$ & -0.005 & $a$ & 0.000 & \\
\hline 5 & 0.001 & $a$ & -0.003 & $\mathrm{a}$ & 0.000 & $a$ & 0.000 & & 0.004 & & -0.004 & $a$ & 0.002 & $a$ & 0.004 & & -0.001 & \\
\hline 6 & 0.003 & & -0.001 & & 0.001 & $b$ & -0.007 & $a$ & 0.001 & & 0.000 & & 0.000 & $a$ & 0.000 & $\mathrm{~b}$ & 0.001 & \\
\hline 7 & 0.004 & & 0.000 & C & 0.001 & $a$ & 0.001 & $a$ & \begin{tabular}{|l|}
-0.002 \\
\end{tabular} & & \begin{tabular}{|l|}
-0.002 \\
\end{tabular} & $a$ & 0.001 & $a$ & 0.001 & 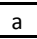 & 0.005 & \\
\hline 8 & 0.002 & & \begin{tabular}{|l|}
-0.002 \\
\end{tabular} & & 0.002 & & 0.004 & & 0.002 & & 0.005 & & -0.001 & $a$ & 0.001 & & 0.001 & a \\
\hline 9 & 0.001 & & -0.002 & $\mathrm{D}$ & 0.003 & & 0.000 & & \begin{tabular}{|l|}
-0.004 \\
\end{tabular} & $a$ & -0.001 & $a$ & -0.002 & & 0.000 & & 0.002 & $\mathrm{c}$ \\
\hline 10 & 0.003 & & -0.004 & $b$ & -0.002 & $a$ & -0.003 & $a$ & 0.006 & & \begin{tabular}{|l|}
-0.002 \\
\end{tabular} & $a$ & 0.002 & & 0.001 & & 0.001 & \\
\hline
\end{tabular}

C: Neutral News

\begin{tabular}{|c|c|c|c|c|c|c|c|c|c|c|c|c|c|c|c|c|}
\hline \multirow{2}{*}{$\stackrel{\mathscr{g}}{\underline{E}}$} & \multicolumn{2}{|c|}{ ZEW (1) } & \multicolumn{2}{|l|}{ IFO (1) } & \multicolumn{2}{|c|}{$\begin{array}{l}\text { Ind. Prod. } \\
\text { (3) }\end{array}$} & \multicolumn{2}{|c|}{ GDP (4) } & \multicolumn{2}{|c|}{$\begin{array}{c}\text { Retail Sales } \\
\text { (7) }\end{array}$} & \multicolumn{2}{|c|}{$\begin{array}{c}\text { Trade } \\
\text { Balance (2) } \\
\end{array}$} & \multicolumn{2}{|c|}{ CPI (19) } & \multicolumn{2}{|l|}{ PPI (14) } \\
\hline & AR \% & & AR \% & & AR \% & & AR \% & & AR \% & & AR \% & & AR \% & & AR \% & \\
\hline-5 & 0.007 & & 0.008 & & 0.011 & & -0.007 & $a$ & -0.003 & & 0.000 & & 0.000 & & -0.002 & 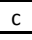 \\
\hline-4 & -0.015 & b & \begin{tabular}{|l|}
-0.010 \\
\end{tabular} & & -0.012 & $a$ & 0.007 & & 0.002 & & 0.000 & & \begin{tabular}{|l|}
-0.003 \\
\end{tabular} & $b$ & 0.000 & $\mathrm{~b}$ \\
\hline-3 & -0.037 & $b$ & 0.000 & & 0.009 & & 0.002 & & -0.003 & $b$ & -0.008 & & 0.000 & & 0.002 & \\
\hline-2 & -0.007 & & 0.008 & & 0.004 & & 0.005 & & 0.007 & & 0.000 & & 0.014 & & \begin{tabular}{|l|}
-0.007 \\
\end{tabular} & \\
\hline-1 & 0.026 & & -0.014 & c & 0.010 & & -0.005 & $\mathrm{~b}$ & 0.006 & & 0.004 & & -0.008 & & -0.002 & c \\
\hline 0 & 0.007 & & \begin{tabular}{|l|}
-0.007 \\
\end{tabular} & & 0.001 & & 0.001 & & 0.000 & & -0.002 & & \begin{tabular}{|l|}
-0.001 \\
\end{tabular} & $a$ & \begin{tabular}{|l|}
-0.003 \\
\end{tabular} & $\mathrm{a}$ \\
\hline 1 & -0.004 & & \begin{tabular}{|l|}
-0.007 \\
\end{tabular} & & -0.001 & & 0.016 & & 0.004 & & 0.002 & & \begin{tabular}{|l|}
-0.003 \\
\end{tabular} & $a$ & 0.002 & $\mathrm{~b}$ \\
\hline 2 & -0.011 & $c$ & 0.015 & & 0.002 & & -0.001 & $\mathrm{~b}$ & 0.012 & & 0.000 & & \begin{tabular}{|l|}
-0.001 \\
\end{tabular} & & \begin{tabular}{|l|}
-0.001 \\
\end{tabular} & \\
\hline 3 & -0.007 & C & 0.004 & & 0.000 & $\mathrm{~b}$ & 0.007 & & 0.004 & & -0.002 & & 0.001 & & \begin{tabular}{|l|}
-0.014 \\
\end{tabular} & $\mathrm{a}$ \\
\hline 4 & 0.004 & & -0.018 & $b$ & 0.000 & & 0.002 & & 0.002 & & 0.000 & $\mathrm{c}$ & 0.005 & & 0.002 & \\
\hline 5 & 0.015 & & 0.047 & & 0.011 & & -0.004 & $b$ & 0.003 & & 0.000 & $\mathrm{C}$ & -0.003 & $b$ & -0.001 & \\
\hline 6 & -0.007 & & 0.000 & & 0.003 & & 0.002 & & -0.001 & & & & -0.005 & $b$ & \begin{tabular}{|l|}
-0.001 \\
\end{tabular} & \\
\hline 7 & 0.004 & & 0.000 & & -0.009 & a & 0.005 & & 0.006 & & 0.002 & & \begin{tabular}{|l|}
-0.003 \\
\end{tabular} & $a$ & 0.002 & $\mathrm{c}$ \\
\hline 8 & 0.018 & & 0.000 & & 0.001 & & -0.005 & $\mathrm{~b}$ & 0.006 & & 0.002 & & \begin{tabular}{|l|}
-0.002 \\
\end{tabular} & $a$ & 0.000 & $a$ \\
\hline 9 & -0.007 & & \begin{tabular}{|l|}
-0.010 \\
\end{tabular} & & 0.000 & & -0.003 & & -0.001 & $a$ & 0.002 & & \begin{tabular}{|l|}
-0.001 \\
\end{tabular} & & 0.001 & $\mathrm{~b}$ \\
\hline 10 & 0.000 & & -0.021 & $b$ & 0.001 & & 0.002 & & -0.002 & & 0.002 & & 0.000 & & 0.001 & \\
\hline
\end{tabular}

Note: Table contains values of mean abnormal percentage returns (AR\%) on a currency pair as an effect of the macroeconomic announcements in the event window running from -5 to 10 minutes; announcement occurs at 0 minute. We report statistical significance (denoted by a symbol) at the 1 (a), 5 (b), and 10\% (c) levels based on the Corrado-Zivney Tcz statistics with the corresponding critical values of 2,58 (1\%), 1,96 (5\%), and 1,65 (10\%). The sample runs from January 3, 2011 to December 31, 2015. The announcements are abbreviated as follows: , ZEW - German Economic Sentiment Index, PMI - Purchasing Managers' Indices from Manufacturing and Services Sectors, IFO - German Business Climate Index, GDP - Gross Domestic Product, CPI - Consumer Price Index, PPI - Producer Price Index. Number of examined events is indicated in the parentheses. 
Table A2: Effect of Macroeconomic Announcements on Abnormal Returns of PLN/EUR

A: Good News

\begin{tabular}{|c|c|c|c|c|c|c|c|c|c|c|c|c|c|c|c|c|c|c|}
\hline & \multicolumn{2}{|c|}{ ZEW (24) } & \multicolumn{2}{|c|}{ PMI (13) } & \multicolumn{2}{|l|}{ IFO (31) } & \multicolumn{2}{|c|}{$\begin{array}{l}\text { Ind. Prod. } \\
\text { (24) }\end{array}$} & \multicolumn{2}{|l|}{ GDP (9) } & \multicolumn{2}{|c|}{\begin{tabular}{|c|} 
Retail Sales \\
(23)
\end{tabular}} & \multicolumn{2}{|c|}{\begin{tabular}{|c|} 
Trade \\
Balance (23)
\end{tabular}} & \multicolumn{2}{|l|}{ CPI (21) } & \multicolumn{2}{|c|}{ PPI (24) } \\
\hline & AR \% & & AR \% & & AR \% & & AR \% & & $\mathrm{R} \%$ & & AR \% & & AR \% & & R\% & & AR \% & \\
\hline-5 & -0.003 & c & 0.012 & & .001 & & 0.001 & & 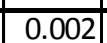 & & 0.000 & & 0.001 & & -0.001 & & -0.003 & \\
\hline-4 & 0.001 & & & & 002 & -1 & -0.001 & & & & 0.002 & $\mathrm{~b}$ & .005 & a & 0.006 & & & \\
\hline-3 & & & & & & a & & $\mathrm{a}$ & & & & $a$ & & & & & & \\
\hline-2 & & & & & & & & & & & & & & & & & & \\
\hline-1 & & & & & & & 0.1 & & & & & & & & & & & \\
\hline 0 & & & & & & $a$ & 0.0 & & & & & & 2 & & & & & \\
\hline 1 & & & & & 0.004 & & -0.006 & & & & 01 & $b$ & 0.004 & & & & & $\mathrm{~b}$ \\
\hline 2 & & & & a & & $\mathrm{b}$ & & b & & $a$ & & & & $a$ & & & & \\
\hline & & & & D & & & & & & & & & & & & & & \\
\hline & & & & & & $\mathrm{b}$ & -0.0 & & & & & & -0. & & & D & & \\
\hline 5 & & $c$ & & $a$ & & - & \begin{tabular}{l|l}
0.002 \\
\end{tabular} & $h$ & -0.0 & & 0.005 & & 0.003 & & & $\mathrm{a}$ & & \\
\hline 6 & -0.005 & $a$ & & & -0 & $\mathrm{a}$ & 0.002 & & 0.0 & & \begin{tabular}{|l|}
-0.002 \\
\end{tabular} & $b$ & \begin{tabular}{l|l}
0.002 \\
\end{tabular} & & & & & \\
\hline- & & & & & .011 & $a$ & -0.003 & & & & \begin{tabular}{|l|}
-0.002 \\
\end{tabular} & $\mathrm{~b}$ & 0.001 & & -0.001 & & & \\
\hline 8 & & & & 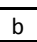 & & & & & & & & 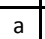 & & & & & & \\
\hline 1 & & & & & & 0 & & & & & & a & & & & & & \\
\hline 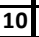 & 0.002 & & -0.008 & & -0.006 & $\mathrm{a}$ & -0.003 & $\mathrm{a}$ & -0.002 & & -0.001 & $b$ & -0.005 & & 0.001 & & -0.002 & \\
\hline
\end{tabular}

B: Bad News

\begin{tabular}{|c|c|c|c|c|c|c|c|c|c|c|c|c|c|c|c|c|c|c|}
\hline \multirow[b]{2}{*}{$\underline{\mathrm{s}}$} & \multicolumn{2}{|c|}{ ZEW (32) } & \multicolumn{2}{|c|}{ PMI (19) } & \multicolumn{2}{|c|}{ IFO (26) } & \multicolumn{2}{|c|}{$\begin{array}{c}\text { Ind. Prod. } \\
\text { (33) }\end{array}$} & \multicolumn{2}{|c|}{ GDP (7) } & \multicolumn{2}{|c|}{$\begin{array}{c}\text { Retail Sales } \\
\text { (29) } \\
\end{array}$} & \multicolumn{2}{|c|}{\begin{tabular}{|c|} 
Trade \\
Balance (30) \\
\end{tabular}} & \multicolumn{2}{|c|}{ CPI (18) } & \multicolumn{2}{|l|}{ PPI (20) } \\
\hline & AR $\%$ & & AR \% & & AR \% & & AR $\%$ & & AR $\%$ & & AR $\%$ & & AR \% & & AR \% & & AR $\%$ & \\
\hline \begin{tabular}{|l|l}
-5 \\
\end{tabular} & -0.003 & $a$ & \begin{tabular}{|l|}
-0.002 \\
\end{tabular} & c & 0.001 & & 0.000 & $\mathrm{~b}$ & 0.002 & & -0.003 & $a$ & \begin{tabular}{|l|}
-0.011 \\
\end{tabular} & $a$ & 0.005 & & -0.009 & $a$ \\
\hline \begin{tabular}{|l|l|}
-4 & \\
\end{tabular} & 0.005 & & \begin{tabular}{|c|}
-0.007 \\
\end{tabular} & $a$ & 0.004 & & 0.000 & $a$ & 0.001 & & \begin{tabular}{|l|}
-0.003 \\
\end{tabular} & $a$ & 0.001 & & \begin{tabular}{l|}
002 \\
\end{tabular} & & -0.002 & $\mathrm{~b}$ \\
\hline-3 & -0.002 & $a$ & $\mid-0.022$ & $a$ & -0.001 & $a$ & -0.002 & $\mathrm{~b}$ & -0.005 & $a$ & 0.004 & c & 0.001 & $a$ & -0.004 & 0 & 0.001 & \\
\hline-2 & 0.002 & & \begin{tabular}{|l|}
-0.004 \\
\end{tabular} & $\mathrm{~b}$ & -0.005 & - & 0.001 & & \begin{tabular}{|l|}
-0.002 \\
\end{tabular} & & \begin{tabular}{|l|}
-0.003 \\
\end{tabular} & $\mathrm{~b}$ & 0.009 & & -0.001 & & 0.005 & \\
\hline-1 & -0.007 & a & \begin{tabular}{|l|l|}
-0.019 \\
\end{tabular} & $a$ & -0.003 & $h$ & -0.001 & $a$ & 0.004 & & 0.000 & & 0.005 & & -0.002 & & 0.008 & \\
\hline 0 & 0.000 & $\mathrm{~b}$ & $\mid-0.004$ & $\mathrm{~b}$ & 0.012 & & \begin{tabular}{|l|}
-0.002 \\
\end{tabular} & $a$ & -0.004 & & 0.000 & c & -0.004 & $a$ & 0.004 & & 0.007 & \\
\hline 1 & 0.000 & $\mathrm{~b}$ & \begin{tabular}{l|l}
0.007 \\
\end{tabular} & & \begin{tabular}{l|l}
0.000 \\
\end{tabular} & a & $\mid-0.001$ & $b$ & 0.012 & & $\mid-0.001$ & $b$ & $\mid-0.001$ & & 0.001 & & 0.002 & \\
\hline 2 & 0.009 & & -0.009 & $a$ & 0.008 & & \begin{tabular}{|c|}
-0.002 \\
\end{tabular} & $a$ & -0.007 & $b$ & 0.000 & $a$ & \begin{tabular}{|l|}
0.000 \\
\end{tabular} & & 0.005 & & -0.003 & b \\
\hline 3 & 0.000 & & 005 & & \begin{tabular}{|c|}
0.001 \\
\end{tabular} & & 0.0 & $a$ & $\mid-0.003$ & c & 0.003 & & 0.006 & & 0.001 & & 0.002 & \\
\hline 4 & 0.004 & & \begin{tabular}{|l|}
-0.003 \\
\end{tabular} & & -0.006 & $\mathrm{a}$ & 0.002 & $r$ & $\mid-0.012$ & $\mathrm{a}$ & \begin{tabular}{|l|}
-0.002 \\
\end{tabular} & $\mathrm{~b}$ & \begin{tabular}{|c|}
-0.003 \\
\end{tabular} & $\mathrm{~b}$ & 0.002 & & -0.002 & c \\
\hline 5 & 0.006 & & 0.011 & & 0.002 & & 0.000 & $\mathrm{~b}$ & -0.004 & $b$ & \begin{tabular}{|c|}
-0.003 \\
\end{tabular} & $a$ & \begin{tabular}{|c|}
-0.001 \\
\end{tabular} & $\mathrm{~b}$ & -0.007 & & -0.006 & 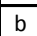 \\
\hline 6 & 0.001 & & \begin{tabular}{|l|}
-0.010 \\
\end{tabular} & $a$ & 0.000 & & \begin{tabular}{|l|}
-0.002 \\
\end{tabular} & $a$ & \begin{tabular}{|l}
-0.008 \\
\end{tabular} & $a$ & 0.003 & & 0.000 & c & -0.004 & b & 0.001 & \\
\hline 7 & -0.002 & c & \begin{tabular}{|c|}
-0.006 \\
\end{tabular} & $a$ & 0.004 & & 0.002 & $a$ & -0.001 & $\mathrm{~b}$ & \begin{tabular}{|c|}
-0.002 \\
\end{tabular} & $a$ & 0.000 & $c$ & -0.005 & D & 0.001 & \\
\hline 8 & 0.000 & $a$ & \begin{tabular}{|l|}
-0.007 \\
\end{tabular} & $a$ & 0.003 & & \begin{tabular}{|l|}
-0.001 \\
\end{tabular} & $\mathrm{a}$ & \begin{tabular}{|l|}
-0.003 \\
\end{tabular} & & \begin{tabular}{|l|}
-0.001 \\
\end{tabular} & $a$ & 0.000 & & $\begin{array}{l}0.002 \\
\end{array}$ & & 0.002 & \\
\hline 9 & 0.001 & & 0.000 & & -0.002 & & 0.000 & - & \begin{tabular}{|c|}
-0.003 \\
\end{tabular} & $b$ & $\mid-0.003$ & a & -0.004 & $\mathrm{~b}$ & 0.004 & & 0.003 & \\
\hline 10 & 0.001 & & 0.004 & & -0.006 & $\mathrm{a}$ & 0.002 & $\mathrm{~b}$ & 0.000 & & \begin{tabular}{|c|}
-0.002 \\
\end{tabular} & b & \begin{tabular}{|c|}
-0.002 \\
\end{tabular} & & -0.002 & & 0.001 & \\
\hline
\end{tabular}

C: Neutral News

\begin{tabular}{|c|c|c|c|c|c|c|c|c|}
\hline & ZEW (1) & IFO(1) & \begin{tabular}{|c|} 
Ind. Prod. \\
(3) \\
\end{tabular} & GDP (4) & $\begin{array}{c}\text { Retail } \\
\text { Sales (7) }\end{array}$ & \begin{tabular}{|c|} 
Trade \\
Balance (2) \\
\end{tabular} & PI & PPI \\
\hline & AR\% & R\% & AR \% & AR \% & $\mathrm{R} \%$ & ३\% & AR \% & AR \% \\
\hline-5 & -0.002 & & & & & & & 00005 \\
\hline-4 & & & & & & & & \\
\hline-3 & & & & & & & & 7 \\
\hline-2 & -0.0 & & & & & & & \\
\hline & & & & & & & & \\
\hline 0 & & & & & & & & 1 \\
\hline & & & & & & & & \\
\hline 2 & & & & & & & & \begin{tabular}{|l|l|}
$\mathrm{a}$ & -0 \\
\end{tabular} \\
\hline 3 & 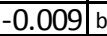 & & & & & & & \\
\hline 4 & & & & & & & & \\
\hline & & & & & & & & \\
\hline 6 & & $9 \mathrm{~b}$ & & & -0. & & & $\overline{02}$ \\
\hline 7 & & -0.0 & & & & 07 & & \\
\hline 8 & & & & & & & & \\
\hline 9 & & & & & & & & \\
\hline & & & -0.004 & & & & & \\
\hline
\end{tabular}

Note: Table contains values of mean abnormal percentage returns (AR\%) on a currency pair as an effect of the macroeconomic announcements in the event window running from -5 to 10 minutes; announcement occurs at 0 minute. We report statistical significance (denoted by a symbol) at the 1 (a), 5 (b), and $10 \%$ (c) levels based on the Corrado-Zivney Tcz statistics with the corresponding critical values of 2,58 (1\%), 1,96 (5\%), and 1,65 (10\%). The sample runs from January 3, 2011 to December 31, 2015. The announcements are abbreviated as follows: , ZEW - German Economic Sentiment Index, PMI - Purchasing Managers' Indices from Manufacturing and Services Sectors, IFO - German Business Climate Index, GDP - Gross Domestic Product, CPI - Consumer Price Index, PPI - Producer Price Index. Number of examined events is indicated in the parentheses. 
Table A3: Effect of Macroeconomic Announcements on Abnormal Returns of HUF/EUR

A: Good News

\begin{tabular}{|c|c|c|c|c|c|c|c|c|c|c|c|c|c|c|c|c|c|c|}
\hline & \multicolumn{2}{|c|}{ ZEW (1) } & \multicolumn{2}{|c|}{ PMI (13) } & \multicolumn{2}{|l|}{ IFO (31) } & \multicolumn{2}{|c|}{\begin{tabular}{|c|} 
Ind. Prod. \\
(24) \\
\end{tabular}} & \multicolumn{2}{|l|}{ GDP (9) } & \multicolumn{2}{|c|}{\begin{tabular}{|c|} 
Retail Sales \\
(23)
\end{tabular}} & \multicolumn{2}{|c|}{\begin{tabular}{|c|} 
Trade \\
Balance (23) \\
\end{tabular}} & \multicolumn{2}{|l|}{ CPI (21) } & \multicolumn{2}{|c|}{ PPI (24) } \\
\hline & AR $\%$ & & AR $\%$ & & AR $\%$ & & AR $\%$ & & AR $\%$ & & AR $\%$ & & AR $\%$ & & AR $\%$ & & AR $\%$ & \\
\hline-5 & 0.005 & & & & & $a$ & & & & & & & 0 & & & & -0.003 & \\
\hline-4 & -0.00 & & & & .001 & & 0.002 & & (2) & & 012 & & 0.004 & & & & & c \\
\hline-3 & 0.00 & $b$ & & & & d & & & & & & $\mathrm{b}$ & $0 \mathrm{~s}$ & $\mathrm{~b}$ & & & & d \\
\hline-2 & & & & & & -1 & & & & & & $a$ & & & & & & 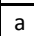 \\
\hline \begin{tabular}{|l|}
-1 \\
\end{tabular} & & & & & & & & & & & & & & & & & & \\
\hline 0 & & & & & & & & & & & & & & & & & & \\
\hline \begin{tabular}{|l|}
1 \\
\end{tabular} & 0.0 & & & & -0.0 & $a$ & \begin{tabular}{l|l}
0.000 \\
\end{tabular} & & -0.0 & & $\mid-0.002$ & $b$ & -0.004 & $\mathrm{~b}$ & & & & \\
\hline 2 & $0 \cap 05$ & & & $c$ & & & & & & & & & & $\mathrm{~b}$ & & & & \\
\hline 3 & & & & b & & b & & & & & & d & & - & & & & \\
\hline 4 & & & & \begin{tabular}{|l}
$a$ \\
\end{tabular} & & & & & & & & $a$ & & & & & & \\
\hline \begin{tabular}{|l|}
5 \\
\end{tabular} & & $a$ & & & & $a$ & & & & & & & 2 & & & & & \\
\hline 6 & $\mid-0.008$ & $a$ & & & 11 & $a$ & -0.006 & $a^{\circ}$ & & & -0.001 & $a$ & 0.000 & & & & & $a$ \\
\hline 7 & 0.004 & & 3 & & & $\mathrm{a}$ & \begin{tabular}{l|}
0.002 \\
\end{tabular} & & -0 . & & & -1 & 0.011 & & & & & \\
\hline \begin{tabular}{|l|}
8 \\
\end{tabular} & & $a$ & & C & 4 & $a$ & -0.006 & & & & & b & Do & & & & & \\
\hline 13 & & 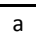 & & $a$ & & & & & & & & 0 & & & & & & \\
\hline & 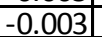 & & 0.004 & $=$ & $\mid$ & & -0.004 & & (1) & & -0.001 & & -0.011 & & -0.003 & & 04 & \\
\hline
\end{tabular}

B: Bad News

\begin{tabular}{|c|c|c|c|c|c|c|c|c|c|c|c|c|c|c|c|c|c|c|}
\hline & \multicolumn{2}{|c|}{ ZEW (32) } & \multicolumn{2}{|c|}{ PMI (19) } & \multicolumn{2}{|c|}{ IFO (26) } & \multicolumn{2}{|c|}{$\begin{array}{l}\text { Ind. Prod. } \\
\text { (33) }\end{array}$} & \multicolumn{2}{|l|}{ GDP (7) } & \multicolumn{2}{|c|}{$\begin{array}{c}\text { Retail Sales } \\
\text { (29) }\end{array}$} & \multicolumn{2}{|c|}{\begin{tabular}{|c|} 
Trade \\
Balance (30)
\end{tabular}} & \multicolumn{2}{|c|}{ CPI (18) } & \multicolumn{2}{|l|}{ PPI (20) } \\
\hline & AR \% & & AR \% & & AR \% & & AR\% & & AR\% & & AR \% & & AR \% & & AR \% & & AR \% & \\
\hline-5 & $\overline{.0 C}$ & $\mathrm{~b}$ & .004 & $\mathrm{~b}$ & & $\bar{c}$ & $\overline{6}$ & & & & 002 & & 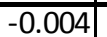 & & & & $\overline{003}$ & \\
\hline-4 & & & & & & 4 & & a & & & & & & & & & & \\
\hline-3 & 0.0 & & & 3 & & & 0 & & 0 & & 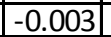 & & 07 & & & & & \\
\hline-2 & $\overline{0.0}$ & $\mathrm{~b}$ & & & & $\mathrm{~b}$ & Do & $a$ & & $\mathrm{~b}$ & & & $\overline{08}$ & & & & & \\
\hline-1 & -0.011 & $\mathrm{a}$ & 9 & $\mathrm{~b}$ & 50 & $a$ & -0.016 & a & & & & & 0.000 & $a$ & & & & \\
\hline 0 & & $a$ & & $\mathrm{~b}$ & & $\mathrm{~b}$ & & $\mathrm{a}$ & & & & & 0.001 & & & & & \\
\hline- & & c & & $\mathrm{b}$ & & $a$ & & b & & & & & & $\mathrm{b}$ & & & & \\
\hline 2 & 0. & & & & & & & & & & -0 & & \begin{tabular}{|l|}
-0.012 \\
\end{tabular} & & & & & \\
\hline 3 & & & & & & & 02 & c & & $\mathrm{b}$ & 06 & & \begin{tabular}{|l|}
0.003 \\
\end{tabular} & & & & & \\
\hline 4 & & & & $\mathrm{~b}$ & 0.000 & $\mathrm{~b}$ & 0.000 & $\mathrm{a}$ & & $\mathrm{a}$ & -0.001 & $\mathrm{a}$ & -0.010 & $\mathrm{a}$ & -0 . & & $\begin{array}{l}-0.003 \\
\end{array}$ & \\
\hline 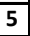 & & & & c & & & & & & $b$ & & & $\mid-0.010$ & $\mathrm{a}$ & -0.002 & & & \\
\hline 6 & & & & & & a & & & & & & & & & & & & \\
\hline 7 & & & & D & & $b_{1}$ & & c & & & & & & & & & & \\
\hline 8 & 2 & $r$ & & -1 & & $\mathrm{a}$ & 05 & & & b & -0.005 & $\mathrm{a}$ & \begin{tabular}{|l|}
-0.002 \\
\end{tabular} & $\mathrm{a}$ & & & -0. & \\
\hline 9 & 0.001 & $b$ & $\mid-0.004$ & \begin{tabular}{|l|}
$a$ \\
\end{tabular} & -0.002 & $\mathrm{a}$ & \begin{tabular}{|c|}
-0.004 \\
\end{tabular} & $\mathrm{~b}$ & -0. & $\mathrm{~b}$ & 0.005 & & $\begin{array}{ll}0.003 \\
\end{array}$ & & -0.008 & & 0.002 & \\
\hline 10 & \begin{tabular}{|c|}
-0.001 \\
\end{tabular} & $b$ & -0.003 & \begin{tabular}{|l|}
$c$ \\
\end{tabular} & 0.006 & & 0.001 & & -0.006 & & $\mid-0.001$ & & 0.008 & & -0.006 & & -0.006 & \\
\hline
\end{tabular}

C: Neutral News

\begin{tabular}{|c|c|c|c|c|c|c|c|c|}
\hline & ZEW (1) & o(1) & $\begin{array}{c}\text { Ind. Prod. } \\
\text { (3) }\end{array}$ & GDP (4) & $\begin{array}{c}\text { Retail } \\
\text { Sales (7) }\end{array}$ & \begin{tabular}{|c|} 
Trade \\
Balance (2)
\end{tabular} & PI (18) & PI (14 \\
\hline$\xi$ & AR $\%$ & A & AR $\%$ & AR \% & AR \% & AR \% & AR \% & AR \% \\
\hline-5 & & & & & & & & 2 \\
\hline-4 & & & \begin{tabular}{ll|l}
$77 b$ \\
\end{tabular} & 4 & & & & \\
\hline-3 & & & & & & & & \\
\hline-2 & & & & & & & & \\
\hline-1 & & & & & & & & \\
\hline 0 & & & & & & & & \\
\hline 1 & & & $\begin{array}{ll}26 \mathrm{~b} \\
\mathrm{n}\end{array}$ & & & & & \\
\hline 2 & & & & & & & & \\
\hline 3 & & & & & & & & \\
\hline 4 & & & & & & $-0.014 \mid b$ & & -0 \\
\hline 5 & -0.0 & & & & & & & -0 \\
\hline 6 & & & & & & & & \\
\hline 7 & & & 5 & & & & & \\
\hline 8 & & & & & & & & \\
\hline 9 & \begin{tabular}{l|l}
7 & $c$ \\
\end{tabular} & & & & & -0. & & -0 \\
\hline & \begin{tabular}{|l|}
-0.007 \\
\end{tabular} & 321 & 0.002 & 0.1 & 10 & 0.0 & -0.1 & -0.006 \\
\hline
\end{tabular}

Note: Table contains values of mean abnormal percentage returns (AR\%) on a currency pair as an effect of the macroeconomic announcements in the event window running from -5 to 10 minutes; announcement occurs at 0 minute. We report statistical significance (denoted by a symbol) at the 1 (a), 5 (b), and 10\% (c) levels based on the Corrado-Zivney Tcz statistics with the corresponding critical values of 2,58 (1\%), 1,96 (5\%), and 1,65 (10\%). The sample runs from January 3, 2011 to December 31, 2015. The announcements are abbreviated as follows: , ZEW - German Economic Sentiment Index, PMI - Purchasing Managers' Indices from Manufacturing and Services Sectors, IFO - German Business Climate Index, Ind. Prod. - Industrial Production, GDP - Gross Domestic Product, CPI - Consumer Price Index, PPI - Producer Price Index. Number of examined events is indicated in the parentheses. 
Table A4: Effect of Macroeconomic Announcements on Abnormal Returns of CZK/USD

A: Good News

\begin{tabular}{|c|c|c|c|c|c|c|c|c|c|c|c|c|c|c|c|c|c|c|c|c|}
\hline \multirow{2}{*}{$\stackrel{\text { gू }}{\underline{E}}$} & \multicolumn{2}{|c|}{ NFP (30) } & \multicolumn{2}{|c|}{$\begin{array}{l}\text { PMI Man } \\
\text { (31) }\end{array}$} & \multicolumn{2}{|c|}{$\begin{array}{c}\text { PMI } \\
\text { Services (30) }\end{array}$} & \multicolumn{2}{|c|}{\begin{tabular}{|c} 
Retail Sales \\
(18)
\end{tabular}} & \multicolumn{2}{|l|}{ GDP (7) } & \multicolumn{2}{|c|}{$\begin{array}{l}\text { Ind. Prod. } \\
\text { (12) }\end{array}$} & \multicolumn{2}{|c|}{$\begin{array}{l}\text { Core DGO } \\
\text { (20) }\end{array}$} & \multicolumn{2}{|c|}{\begin{tabular}{|c|} 
Trade \\
Balance (24)
\end{tabular}} & \multicolumn{2}{|l|}{ CPI (16) } & \multicolumn{2}{|l|}{ PPI (16) } \\
\hline & AR \% & & & & AR \% & & & & AR \% & & & & & & & & AR \% & & AR \% & \\
\hline-5 & & & & & & & & $b_{0}$ & & & & & & & & a & & & & \\
\hline-4 & & & & & & & & & & & & & & & & & & & & \\
\hline-3 & .0 & & & b & & & & & & & & & & & & b & & & & \\
\hline & $-0,00$ & & & & & & & & & & & & & & & $c$ & & & & \\
\hline-1 & & & & $a$ & & $a$ & & $a$ & & & & & & & & $a$ & & & & \\
\hline 0 & & & & & & & & & & & & & & & & & & & & \\
\hline 1 & & & & & & & & & & & & & & & & & & & & \\
\hline 2 & & $b$ & & & & & & & & & & & & 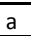 & & 7 & & $D$ & & \\
\hline 3 & & & & 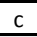 & & & & $b$ & -0.027 & & & & & & & & & & 0.011 & \\
\hline 4 & & & & a & & $c$ & & & & & & & & & & & & & & \\
\hline 5 & & a & & 3 & & & & & & & & & & & & a & & & & \\
\hline & & c & & $a$ & & & & & & & & & & & & & & & & \\
\hline & & & & & & & & & & & & & & & & & & & & \\
\hline 8 & & & & b & & & & & & & & & & & & & & a & & \\
\hline 9 & -0.014 & $a$ & -0.003 & $a$ & 0.004 & & 16 & & -0. & & 0.1 & 策 & & & -0. & $a$ & $\mid-0.007$ & 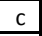 & 0.021 & \\
\hline & -0.014 & $\mathrm{a}$ & 0.002 & & -0.006 & - & -0.003 & $\sigma^{2}$ & 0.012 & & 0.000 & $c$ & \begin{tabular}{l|l}
0.000 \\
\end{tabular} & D & -0.004 & $b$ & 0.000 & & 0.005 & \\
\hline
\end{tabular}

B: Bad News

\begin{tabular}{|c|c|c|c|c|c|c|c|c|c|c|c|c|c|c|c|c|c|c|c|c|}
\hline \multirow{2}{*}{$\stackrel{\mathscr{\Xi}}{\underline{E}}$} & \multicolumn{2}{|c|}{ NFP (29) } & \multicolumn{2}{|c|}{$\begin{array}{l}\text { PMI Man. } \\
\text { (28) }\end{array}$} & \multicolumn{2}{|c|}{$\begin{array}{c}\text { PMI } \\
\text { Services (26) }\end{array}$} & \multicolumn{2}{|c|}{\begin{tabular}{|c} 
Retail Sales \\
(24) \\
\end{tabular}} & \multicolumn{2}{|l|}{ GDP (11) } & \multicolumn{2}{|c|}{$\begin{array}{l}\text { Ind. Prod. } \\
\text { (14) }\end{array}$} & \multicolumn{2}{|c|}{$\begin{array}{c}\text { Core DGO } \\
(38)\end{array}$} & \multicolumn{2}{|c|}{\begin{tabular}{|c|} 
Trade \\
Balance (26)
\end{tabular}} & \multicolumn{2}{|l|}{ CPI (5) } & \multicolumn{2}{|l|}{ PPI (17) } \\
\hline & AR \% & & AR\% & & AR \% & & AR \% & & R\% & & AR\% & & AR\% & & AR \% & & AR \% & & AR \% & \\
\hline-5 & 0.002 & & & & & c & & & & & & & & & & & & & & \\
\hline-4 & -0. & & & & & & & & & & & & & & & & & & & \\
\hline-3 & 0.0 & & & & & & & & & & & $b$ & & & & & & & & \\
\hline-2 & & & & & & & & & & & & & & & & $a$ & & & & \\
\hline-1 & & & & & & & & & & & & . & & & & & & & & \\
\hline 0 & & & & & & & & & & & & & & & & a & & & & \\
\hline 1 & & & & & & - & & & & & & & & & & & & & & \\
\hline 2 & & & & & & & & & & & & & & & & & & & & \\
\hline 3 & & & & & & $a$ & & & & & & & & & & & & & & \\
\hline 4 & & & & & & $b$ & & & & & & & & & & & & & & \\
\hline 5 & & & & & & 7 & & & & & & & & & & $a$ & & & & \\
\hline 0 & & & & & & & & & & & & & & & & - & & & & \\
\hline$\rightarrow$ & & & & & & & & & & & & & & & & & & & & \\
\hline 8 & & & & & & & & & & & & & & & 04 & $\mathrm{a}$ & & & & \\
\hline \begin{tabular}{l|l|}
9 \\
\end{tabular} & & & & & -0.004 & $d$ & & & & & & $d$ & & & & & -0. & & & \\
\hline & 0.002 & & -0.001 & & -0.005 & 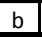 & 0.001 & & 0.000 & & 0.009 & & $\mid-0.013$ & & -0.004 & 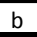 & 0.005 & & -0.004 & \\
\hline
\end{tabular}

C: Neutral News

\begin{tabular}{|c|c|c|c|c|c|c|c|c|c|c|c|c|c|c|c|c|c|c|c|}
\hline \multirow{2}{*}{$\underline{\underline{\underline{\xi}}}$} & \multicolumn{2}{|l|}{ NFP (1) } & PMI Man (1) & \multicolumn{2}{|c|}{$\begin{array}{c}\text { PMI } \\
\text { Services (4) } \\
\end{array}$} & \multicolumn{2}{|c|}{$\begin{array}{c}\text { Retail Sales } \\
\text { (5) }\end{array}$} & \multicolumn{2}{|l|}{ GDP (2) } & \multicolumn{2}{|c|}{$\begin{array}{l}\text { Ind. Prod. } \\
\text { (4) }\end{array}$} & \multicolumn{2}{|c|}{$\begin{array}{c}\text { Core DGO } \\
\text { (1) } \\
\end{array}$} & \multicolumn{2}{|c|}{$\begin{array}{c}\text { Trade } \\
\text { Balance (1) } \\
\end{array}$} & \multicolumn{2}{|c|}{ CPI (18) } & \multicolumn{2}{|l|}{ PPI (6) } \\
\hline & AR\% & & AR\% & AR\% & & AR\% & & AR\% & & AR\% & & AR\% & & AR\% & & AR\% & & AR\% & \\
\hline-5 & 0.032 & & 0.000 & 0.003 & & 0.008 & & -0.005 & & -0.019 & $a$ & \begin{tabular}{|c|}
0.023 \\
\end{tabular} & & -0.026 & & 0.000 & & -0.001 & \\
\hline-4 & -0.092 & & & & & & & & & & & & & & & & & & b \\
\hline-3 & -0.032 & & .0 & 3 & & 9 & & -0.012 & 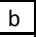 & 0.005 & & -0.009 & & -0.063 & $b_{1}$ & & & -0.014 & \\
\hline-2 & 0.005 & & 0.000 & 0.007 & & 0.005 & & $\begin{array}{l}0.049 \\
\end{array}$ & & -0.009 & & \begin{tabular}{|l|}
0.028 \\
\end{tabular} & & \begin{tabular}{|c|}
0.016 \\
\end{tabular} & & $\begin{array}{l}0.002 \\
\end{array}$ & & -0.001 & \\
\hline-1 & 0.037 & & 000 & 0.011 & & 0.006 & & -0.073 & $\mathrm{a}$ & \begin{tabular}{l|l}
0.018 \\
\end{tabular} & & 0.009 & & 0.000 & & -0.077 & $a$ & $\begin{array}{l}0.026 \\
\end{array}$ & \\
\hline 0 & -0.032 & c & 0.000 & \begin{tabular}{l|l}
0.010 \\
\end{tabular} & & -0.007 & & $\begin{array}{ll}0.022 \\
\end{array}$ & & -0.014 & & -0.005 & & \begin{tabular}{l|l}
0.016 \\
\end{tabular} & & -0.001 & & 0.020 & \\
\hline 1 & & & & & & & & & $\mathrm{~b}$ & & & & & & b & -0.1 & $\mathrm{~b}$ & & \\
\hline 2 & -0.134 & $\mathrm{~b}$ & & 0 & & a & & 0.0 & & & & & & -0.052 & & & & 1 & \\
\hline 3 & 0.011 & & & 0. & & & & -0.051 & $a$ & -0.012 & & & & & & & & -0.016 & 4 \\
\hline 4 & -0.065 & $b$ & 0.000 & 0.024 & & 0.014 & & -0.012 & & -0.006 & $c$ & -0.028 & c & -0.026 & & 0.000 & & \begin{tabular}{|c|}
0.007 \\
\end{tabular} & \\
\hline 5 & -0.059 & $b$ & 0.005 & \begin{tabular}{l|l}
0.010 \\
\end{tabular} & & -0.007 & & -0.012 & & -0.006 & & 0.000 & & 0.026 & & 0.010 & & 0.006 & \\
\hline 6 & -0.155 & b & -0.020 & -0.025 & $\mathrm{~b}$ & & & -0.0 & & & & & & -0.042 & & & & -0.011 & $\mathrm{c}$ \\
\hline 7 & -0.032 & $\mathrm{c}$ & & & & & & & & & & & & & & & & & \\
\hline 8 & 0.037 & & & & & & & & & & & & & & & & b & 15 & \\
\hline 9 & 0.075 & & & \begin{tabular}{l|l}
0.004 \\
\end{tabular} & & -0.022 & D & -0.017 & & j6 & & 14 & & \begin{tabular}{l|l}
0.016 \\
\end{tabular} & & -0. & $b$ & -0.003 & \\
\hline 1 & 0.086 & 0 & -0.035 & \begin{tabular}{|c|}
0.010 \\
\end{tabular} & & \begin{tabular}{|c|}
0.006 \\
\end{tabular} & & 0.037 & & -0.024 & & -0.005 & & -0.052 & & -0.016 & & 0.013 & \\
\hline
\end{tabular}

Note: Table contains values of mean abnormal percentage returns (AR) on a currency pair as an effect of the macroeconomic announcements in the event window running from -5 to 10 minutes; announcement occurs at 0 minute. We report statistical significance (denoted by a symbol) at the 1 (a), 5 (b), and 10\% (c) levels based on the Corrado-Zivney Tcz statistics with the corresponding critical values of 2,58 (1\%), $1,96(5 \%)$, and 1,65 (10\%). The sample runs from January 3, 2011 to December 31, 2015. The announcements are abbreviated as follows: NFP - Nonfarm Payrolls, PMI - Purchasing Managers' Indices from Manufacturing and Services Sectors, GDP - Gross Domestic Product, Core DGO - Core Durable Goods Orders, CPI - Consumer Price Index, PPI - Producer Price Index. Number of examined events is indicated in the parentheses. 
Table A5: Effect of Macroeconomic Announcements on Abnormal Returns of PLN/USD

A: Good News

\begin{tabular}{|c|c|c|c|c|c|c|c|c|c|c|c|c|c|c|c|c|c|c|c|c|}
\hline \multirow[t]{2}{*}{$\underset{\underline{\xi}}{\stackrel{\Xi}{E}}$} & \multicolumn{2}{|c|}{ NFP (30) } & \multicolumn{2}{|c|}{$\begin{array}{l}\text { PMI Man } \\
\text { (31) }\end{array}$} & \multicolumn{2}{|c|}{$\begin{array}{c}\text { PMI } \\
\text { Services (30) }\end{array}$} & \multicolumn{2}{|c|}{\begin{tabular}{|c} 
Retail Sales \\
(18)
\end{tabular}} & \multicolumn{2}{|l|}{ DP (7) } & \multicolumn{2}{|c|}{$\begin{array}{l}\text { Ind. Prod. } \\
\text { (12) }\end{array}$} & \multicolumn{2}{|c|}{$\begin{array}{c}\text { Core DGO } \\
\text { (20) }\end{array}$} & \multicolumn{2}{|c|}{\begin{tabular}{|c} 
Trade \\
Balance (24)
\end{tabular}} & \multicolumn{2}{|l|}{ PI (16) } & \multicolumn{2}{|l|}{ PPI (16) } \\
\hline & AR \% & & AR \% & & AR \% & & AR \% & & AR\% & & AR \% & & AR \% & & AR \% & & AR \% & & AR \% & \\
\hline-5 & & & & & & 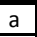 & -0.002 & $\mathrm{a}$ & & & & $a$ & & $a$ & & $a$ & & & & \\
\hline-4 & & & & & & & & & & & & & & & & & & & & \\
\hline & & & & & & & & & & & & & & & & & & & & \\
\hline-2 & & & & & & & & & & & & a & & & & c & & & & \\
\hline-1 & & & & & & 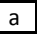 & & $\mathrm{a}$ & & & & & & & & & & & & \\
\hline 0 & & & & & & & & $\mathrm{~h}$ & & & & & & & & & & & & \\
\hline 1 & & b & & & & $a$ & & & & & & & & & & & & & & \\
\hline & & & & & & & & & & & & & & & & & & & & \\
\hline 3 & & & & & & & 14 & D & & & & & & & & & & & & \\
\hline 4 & & & & & & $c$ & & & & & & $b$ & & $a$ & & & & & & \\
\hline 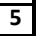 & & & & & & & & $b$ & & & & & & & & & & & & \\
\hline 6 & & & 0.000 & & -0.003 & D & 0.1 & & & & -0.007 & & & & & $d$ & & & & \\
\hline & & & & & & - & & & & & & & & & & & & & & \\
\hline 0 & & & & & & & & & & & & & & & & & & & & \\
\hline 9 & -0.015 & $d^{d}$ & 011 & 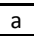 & 0.001 & נ & 0.011 & & 0.006 & & 0.017 & & \begin{tabular}{|l|}
-0.002 \\
\end{tabular} & & -0.005 & D & & & & \\
\hline & \begin{tabular}{|l|}
-0.018 \\
\end{tabular} & & 0.003 & & -0.005 & & -0.006 & & 0.021 & & 0.011 & & $\mid-0.007$ & & -0.002 & & 0.003 & & 0.000 & \\
\hline
\end{tabular}

B: Bad News

\begin{tabular}{|c|c|c|c|c|c|c|c|c|c|c|c|c|c|c|c|c|c|c|c|c|}
\hline \multirow{2}{*}{ 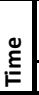 } & \multicolumn{2}{|c|}{ NFP (29) } & \multicolumn{2}{|c|}{$\begin{array}{l}\text { PMI Man } \\
\text { (28) }\end{array}$} & \multicolumn{2}{|c|}{\begin{tabular}{|c|} 
PMI \\
Services (26) \\
\end{tabular}} & \multicolumn{2}{|c|}{$\begin{array}{c}\text { Retail Sales } \\
\text { (24) }\end{array}$} & \multicolumn{2}{|c|}{ GDP (11) } & \multicolumn{2}{|c|}{$\begin{array}{l}\text { Ind. Prod. } \\
\text { (14) }\end{array}$} & \multicolumn{2}{|c|}{$\begin{array}{c}\text { Core DGO } \\
(38)\end{array}$} & \multicolumn{2}{|c|}{\begin{tabular}{|c|} 
Trade \\
Balance (26) \\
\end{tabular}} & \multicolumn{2}{|l|}{ CPI (5) } & \multicolumn{2}{|l|}{ PPI (17) } \\
\hline & AR \% & & AR \% & & & & AR \% & & $\%$ & & AR \% & & AR \% & & AR \% & & AR\% & & $\mathbf{A R}$ & \\
\hline-5 & & & & & & - & & & & & & & & & & & & & & \\
\hline-4 & & & & & & & & & & & & & & & & & & & & \\
\hline-3 & & & & & & & & & & & & & & & & & & & & \\
\hline-2 & & & & & & & & $b$ & & & & & & & & & & & & \\
\hline \begin{tabular}{l|}
-1 \\
\end{tabular} & & & & & & & & & & & & & & & & & & & & \\
\hline 0 & & & & & & & & & & & & & & & & & & & & \\
\hline 1 & & & & & & & & & & & & & & & & & & & & \\
\hline 2 & & & & & & & & & & & & & & & & & & & & \\
\hline 3 & & & & & 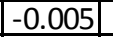 & $\mathrm{a}$ & & & & & & & & & & & & & & \\
\hline 4 & & & & & & & & & & & & & & & & & & & & \\
\hline 5 & & & & & & & & & & & & & & & & $a$ & & & & \\
\hline 6 & & & & & & & & & & & & & & & & $b$ & & & & \\
\hline 7 & & & & & & & & & & & & & & & & & & & & \\
\hline 8 & & & & & & & & & & & & & & & 02 & C & & & & \\
\hline 9 & 0.0 & & & & -0.007 & $d$ & & & & & & $a$ & & & 0.009 & & -0.005 & & & \\
\hline & 0.000 & & -0.006 & & 0.005 & & -0.008 & & -0.006 & 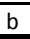 & 0.005 & & -0.009 & & -0.003 & & \begin{tabular}{|l|}
0.006 \\
\end{tabular} & & \begin{tabular}{|l|}
-0.004 \\
\end{tabular} & \\
\hline
\end{tabular}

C: Neutral News

\begin{tabular}{|c|c|c|c|c|c|c|c|c|c|c|c|c|c|c|c|c|c|c|}
\hline \multirow{2}{*}{ 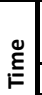 } & \multicolumn{2}{|l|}{ NFP (1) } & \multicolumn{2}{|c|}{ PMI Man (1) } & \multicolumn{2}{|c|}{\begin{tabular}{|c|} 
PMI \\
Services (4) \\
\end{tabular}} & \multicolumn{2}{|c|}{\begin{tabular}{|c|} 
Retail Sales \\
(5) \\
\end{tabular}} & \multicolumn{2}{|l|}{ GDP (2) } & \multicolumn{2}{|c|}{$\begin{array}{l}\text { Ind. Prod. } \\
\text { (4) }\end{array}$} & \multicolumn{2}{|c|}{$\begin{array}{c}\text { Core DGO } \\
\text { (1) }\end{array}$} & \multicolumn{2}{|c|}{\begin{tabular}{|c|} 
Trade \\
Balance (1) \\
\end{tabular}} & CPI (18) & PPI (6) \\
\hline & AR \% & & AR \% & & AR \% & & AR \% & & AR \% & & AR \% & & AR \% & & AR \% & & AR \% & AR \% \\
\hline-5 & 0.051 & c & 0.003 & & -0.008 & & 0.008 & & -0.011 & & -0.023 & $a$ & 0.058 & $b$ & 0.018 & & -0.001 & -0.005 \\
\hline-4 & 0.000 & & & c & 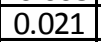 & & & & 0.007 & & 0.008 & & & & & & & \\
\hline-3 & -0.127 & & 0.000 & & Os & & 015 & & 008 & & $\mid-0.007$ & $b$ & \begin{tabular}{|l|l|}
0.024 \\
\end{tabular} & $\mathrm{c}$ & -0.125 & & & \\
\hline-2 & \begin{tabular}{|l|}
0.036 \\
\end{tabular} & & -0.036 & & \begin{tabular}{|l|}
0.024 \\
\end{tabular} & & .012 & & \begin{tabular}{|l|}
0.028 \\
\end{tabular} & $\mathrm{c}$ & $\mid-0.008$ & & $\mid-0.006$ & & \begin{tabular}{|l|}
0.012 \\
\end{tabular} & & & 0. \\
\hline-1 & \begin{tabular}{|l|}
0.115 \\
\end{tabular} & $\mathrm{c}$ & -0.010 & & -0.004 & & 0.014 & & -0.084 & & \begin{tabular}{|l|}
0.012 \\
\end{tabular} & & \begin{tabular}{|l|}
-0.025 \\
\end{tabular} & & -0.042 & & & \begin{tabular}{|l|}
-0.019 \\
\end{tabular} \\
\hline 0 & $\mid-0.049$ & & 0 & & 0.00 & & -0.003 & & \begin{tabular}{|l|}
0.018 \\
\end{tabular} & & $\mid-0.019$ & $b$ & \begin{tabular}{|l|}
-0.009 \\
\end{tabular} & & \begin{tabular}{|l|}
0.015 \\
\end{tabular} & & & \begin{tabular}{|l|}
0.015 \\
\end{tabular} \\
\hline 1 & \begin{tabular}{|l|}
0.0 \\
\end{tabular} & & & & & & & & & & & & & c & & & & \\
\hline 2 & -0.155 & & & & .0 & c & 6 & & 0.077 & 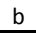 & 2 & & & $\mathrm{c}$ & 0.1 & & & \\
\hline 3 & -0.034 & & & & \begin{tabular}{|l|l}
0.009 \\
\end{tabular} & & 0.028 & & \begin{tabular}{|l}
-0.053 \\
\end{tabular} & & $\mid-0.004$ & & 27 & c & -0.071 & & & -0.021 \\
\hline 4 & $\mid-0.037$ & & 0.062 & $\begin{array}{ll} \\
\end{array}$ & \begin{tabular}{|l|}
0.017 \\
\end{tabular} & & \begin{tabular}{|l|}
0.003 \\
\end{tabular} & & -0.007 & & \begin{tabular}{|l|}
0.001 \\
\end{tabular} & & 0.024 & $\mathrm{c}$ & \begin{tabular}{|l|}
0.012 \\
\end{tabular} & & -0.001 & 0.017 \\
\hline 5 & -0.061 & & -0.003 & & \begin{tabular}{|l|}
0.037 \\
\end{tabular} & \begin{tabular}{|l|}
$\mathrm{b}$ \\
\end{tabular} & \begin{tabular}{|l|}
0.001 \\
\end{tabular} & & -0.026 & & -0.002 & & -0.025 & & \begin{tabular}{|l|}
-0.071 \\
\end{tabular} & & & $\mid-0.005$ \\
\hline 6 & $\mid-0.027$ & & & & -0.0 & & -0.007 & & $\mid-0.053$ & & & & & & -0. & & & \\
\hline 7 & -0.0 & & & & & & & & & & & & & & & & & \\
\hline 8 & & & & & & & & & & & & & & & & & & \\
\hline 9 & -0.121 & & & & -0.006 & & -0.010 & & -0.032 & & 06 & & 09 & & 0.003 & & -0. & 0.007 \\
\hline 10 & 0.012 & & -0.016 & & \begin{tabular}{|l|}
0.055 \\
\end{tabular} & $b$ & -0.009 & & 0.033 & & $\mid-0.010$ & $a$ & $\mid-0.009$ & & -0.048 & & -0.007 & 0.011 \\
\hline
\end{tabular}

Note: Table contains values of mean abnormal percentage returns (AR) on a currency pair as an effect of the macroeconomic announcements in the event window running from -5 to 10 minutes; announcement occurs at 0 minute. We report statistical significance (denoted by a symbol) at the 1 (a), 5 (b), and $10 \%$ (c) levels based on the Corrado-Zivney $T c z$ statistics with the corresponding critical values of 2,58 (1\%), $1,96(5 \%)$, and 1,65 (10\%). The sample runs from January 3, 2011 to December 31, 2015. The announcements are abbreviated as follows: NFP - Nonfarm Payrolls, PMI - Purchasing Managers' Indices from Manufacturing and Services Sectors, GDP - Gross Domestic Product, Core DGO - Core Durable Goods Orders, CPI - Consumer Price Index, PPI - Producer Price Index. Number of examined events is indicated in the parentheses. 
Table A6: Effect of Macroeconomic Announcements on Abnormal Returns of HUF/USD

A: Good News

\begin{tabular}{|c|c|c|c|c|c|c|c|c|c|c|c|c|c|c|c|c|c|c|c|c|}
\hline \multirow{2}{*}{ 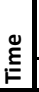 } & \multicolumn{2}{|c|}{ NFP (30) } & \multicolumn{2}{|c|}{$\begin{array}{l}\text { PMI Man } \\
\text { (31) }\end{array}$} & \multicolumn{2}{|c|}{\begin{tabular}{|c|} 
PMI \\
Services (30)
\end{tabular}} & \multicolumn{2}{|c|}{\begin{tabular}{|c|} 
Retail Sales \\
(18)
\end{tabular}} & \multicolumn{2}{|l|}{ GDP (7) } & \multicolumn{2}{|c|}{\begin{tabular}{|c|} 
Ind. Prod. \\
(12)
\end{tabular}} & \multicolumn{2}{|c|}{$\begin{array}{c}\text { Core DGO } \\
\text { (20) }\end{array}$} & \multicolumn{2}{|c|}{\begin{tabular}{|c|} 
Trade \\
Balance (24)
\end{tabular}} & \multicolumn{2}{|c|}{ CPI (16) } & \multicolumn{2}{|l|}{ PPI (16) } \\
\hline & AR \% & & \begin{tabular}{l|l} 
AR \% \\
\end{tabular} & & AR \% & & \begin{tabular}{|l|l|} 
AR $\%$ \\
\end{tabular} & & R\% & & AR\% & & AR\% & & AR\% & & AR\% & & R\% & \\
\hline-5 & \begin{tabular}{|l|}
-0.0 \\
\end{tabular} & & & $a$ & & & & $\mathrm{~b}$ & & & & & & $a$ & & c & & & & \\
\hline-4 & & & & & 4 & $\mathrm{~b}$ & & & & & & & & & & $\mathrm{~b}$ & & & & \\
\hline-3 & & & & & & & & & & & & & & & & & & & & \\
\hline-2 & & & & & & & & & & & & & & & & & & & & \\
\hline-1 & & & & & & & & & & & & & & & & & & & & \\
\hline 0 & & & & & & & & & & & & & & & & & & & & \\
\hline \begin{tabular}{|l|}
1 \\
\end{tabular} & & & & & & & & & & & & & & & & & & & & \\
\hline 2 & & & & & & $\mathrm{a}$ & & & & & & & & $a$ & & $a$ & & & & \\
\hline 3 & & & & & & & & & & & & & & & & $b$ & & & & \\
\hline 4 & & & & & & & & & & & & & & & & & & & & \\
\hline 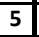 & & & & & & & & & & & & & & & & $a$ & & & & \\
\hline 6 & & J & & & & 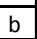 & & & & & & & & & & $\mathrm{a}$ & & & & \\
\hline 7 & & & & & 0.001 & $c$ & & & & & & & & & \begin{tabular}{l|l}
0.003 \\
\end{tabular} & & 06 & & & \\
\hline 8 & 0 & b & & & 0.008 & & & & & & & & & & 0.001 & & -0.008 & & & \\
\hline & 0.0 & 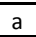 & & c & 0.004 & $c$ & & & & & & & & $\mathrm{~b}$ & -0.009 & $b$ & & & & \\
\hline & -0.005 & 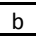 & \begin{tabular}{l|l|}
0.005 \\
\end{tabular} & & -0.003 & b & -0. & & & & 04 & & 8 & & \begin{tabular}{l|l}
0.008 \\
\end{tabular} & & -0.004 & & & \\
\hline
\end{tabular}

\section{B: Bad News}

\begin{tabular}{|c|c|c|c|c|c|c|c|c|c|c|c|c|c|c|c|c|c|c|c|c|}
\hline \multirow{2}{*}{ 竎 } & \multicolumn{2}{|c|}{ NFP (29) } & \multicolumn{2}{|c|}{$\begin{array}{c}\text { PMI Man } \\
\text { (28) }\end{array}$} & \multicolumn{2}{|c|}{\begin{tabular}{|c|} 
PMI \\
Services (26) \\
\end{tabular}} & \multicolumn{2}{|c|}{$\begin{array}{c}\text { Retail Sales } \\
\text { (24) }\end{array}$} & \multicolumn{2}{|c|}{ GDP (11) } & \multicolumn{2}{|c|}{\begin{tabular}{|c} 
Ind. Prod. \\
(14)
\end{tabular}} & \multicolumn{2}{|c|}{$\begin{array}{c}\text { Core DGO } \\
(38)\end{array}$} & \multicolumn{2}{|c|}{\begin{tabular}{|c|} 
Trade \\
Balance (26) \\
\end{tabular}} & \multicolumn{2}{|l|}{ CPI (5) } & \multicolumn{2}{|l|}{ PPI (17) } \\
\hline & AR \% & & AR \% & & AR\% & & AR \% & & $\mathrm{R} \%$ & & AR\% & & AR \% & & AR\% & & K\% & & AR \% & \\
\hline-5 & 0.004 & & & $\mathrm{~b}$ & & $\mathrm{~b}$ & & & & $c$ & & & & 0 & & & & & & \\
\hline-4 & & & & & & & & $a$ & & & & & & & & & & & & \\
\hline-3 & & & & & & 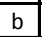 & & & & & & & & & & & & & & \\
\hline-2 & & & & 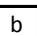 & & & & 4 & & & & & & & & & & & & \\
\hline-1 & & & & & & & & & & & & & & & & & & & & \\
\hline 0 & & $a$ & & & & $a$ & & & & & & & & & & $a$ & & & & \\
\hline 1 & & & & & & & & $a$ & & & & & & & & & & & & \\
\hline 2 & & & & & & & & & & & & & & & & C & & & & \\
\hline 3 & & & & & & & & & & & & 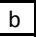 & & & & & & & & \\
\hline 4 & & & & & & & & & & & & & & & & & & & & \\
\hline 5 & 3 & $a$ & & & & $a$ & & & & $\mathrm{~b}$ & & 0 & & 2 & & $a$ & & & & \\
\hline 6 & & & & $\mathrm{~b}$ & & & & $d^{d}$ & & & & & & $b$ & & - & & & & \\
\hline & & & & & & & & & & & & & & & & & & & & \\
\hline 8 & & & & $\mathrm{~b}$ & & & & $a$ & & & & & & & & & & & & \\
\hline J & & & & & & & & & & D & & & & & & & & & & \\
\hline & .004 & Le & -0.005 & & 0.001 & & -0.004 & & -0.006 & & -0.001 & & -0.010 & & -0.002 & & 0.012 & & -0.005 & \\
\hline
\end{tabular}

C: Neutral News

\begin{tabular}{|c|c|c|c|c|c|c|c|c|c|c|c|c|c|c|c|c|c|c|c|}
\hline \multirow[t]{2}{*}{ 竎 } & \multicolumn{2}{|l|}{ NFP (1) } & \multicolumn{2}{|c|}{ PMI Man (1) } & \multicolumn{2}{|c|}{\begin{tabular}{|c|} 
PMI \\
Services (4) \\
\end{tabular}} & \multicolumn{2}{|c|}{\begin{tabular}{|c|} 
Retail Sales \\
(5) \\
\end{tabular}} & \multicolumn{2}{|l|}{ GDP (2) } & \multicolumn{2}{|l|}{$\begin{array}{l}\text { Ind. Prod. } \\
\text { (4) }\end{array}$} & \multirow{2}{*}{ 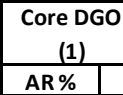 } & \multicolumn{2}{|c|}{\begin{tabular}{|c|} 
Trade \\
Balance (1) \\
\end{tabular}} & \multicolumn{2}{|l|}{ CPI (18) } & \multicolumn{2}{|l|}{ PPI (6) } \\
\hline & AR \% & & $\%$ & & AR \% & & AR \% & & AR \% & & AR \% & & & AR \% & & AR \% & & AR \% & \\
\hline-5 & 0.040 & & & & 030 & 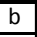 & $\overline{n c}$ & & -0.047 & $\mathrm{~b}$ & \begin{tabular}{l|l}
30 \\
\end{tabular} & $\bar{a}$ & -0.012 & & & & & & \\
\hline-4 & -0.063 & $\mathrm{~b}$ & & & 038 & & 15 & & 21 & $\mathrm{~b}$ & .004 & & & & & 0.006 & & & $\mathrm{~b}$ \\
\hline-3 & 0.009 & & & & & & & & & & & & & & $\mathrm{~b}$ & & c & & \\
\hline-2 & & & & & & & & & & & & & & & & & & & \\
\hline-1 & & & & $\mathrm{~b}$ & & & & $\mathrm{~b}$ & & $\mathrm{a}$ & & & & & $\mathrm{b}$ & & & & \\
\hline 0 & 5 & $\mathrm{~b}$ & & & & & & & & & & & & & & & & & \\
\hline 1 & & & & & & & & & & $=$ & & & & & 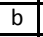 & & & & \\
\hline 2 & 0.1 & & & & & & & & & & & & & & & & & & \\
\hline 3 & & & & & & & & & & c & & $\begin{array}{ll} \\
\end{array}$ & & & & & c & & \\
\hline 4 & & & & & & & & & & & & & & & & & & & \\
\hline 5 & 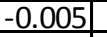 & & & & 0.023 & & & & & & & & & & & & & & \\
\hline 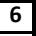 & & & & & & 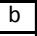 & & & & & & & & & & & & & \\
\hline 7 & 41 & & & & & & & & & & & & & & & & & & \\
\hline 8 & & & & & -0.010 & & & & & & 26 & & & & & & & & \\
\hline 9 & & & & & 02 & & & & & & 22 & & & & & 22 & & & \\
\hline & -0.005 & & -0.021 & & 0. & & 0. & & 0.095 & & & & $0.0<0$ & $-U$. & & IU & & & \\
\hline
\end{tabular}

Note: Table contains values of mean abnormal percentage returns (AR) on a currency pair as an effect of the macroeconomic announcements in the event window running from -5 to 10 minutes; announcement occurs at 0 minute. We report statistical significance (denoted by a symbol) at the 1 (a), 5 (b), and 10\% (c) levels based on the Corrado-Zivney $T c z$ statistics with the corresponding critical values of 2,58 (1\%), 1,96 (5\%), and 1,65 (10\%). The sample runs from January 3, 2011 to December 31, 2015. The announcements are abbreviated as follows: NFP - Nonfarm Payrolls, PMI - Purchasing Managers' Indices from Manufacturing and Services Sectors, GDP - Gross Domestic Product, Core DGO - Core Durable Goods Orders, CPI - Consumer Price Index, PPI - Producer Price Index. Number of examined events is indicated in the parentheses. 
Table A7: Monetary policy settings

Panel A: ECB meetings

\begin{tabular}{|c|c|c|c|c|}
\hline $\begin{array}{c}\text { Day of the ECB } \\
\text { meeting }\end{array}$ & $\begin{array}{c}\text { Time of the } \\
\text { announcement }\end{array}$ & $\begin{array}{c}\text { Deposit } \\
\text { Interest Rate }\end{array}$ & $\begin{array}{c}\text { Main } \\
\text { Refinancing } \\
\text { Operations }\end{array}$ & $\begin{array}{c}\text { Marginal } \\
\text { Lending } \\
\text { Facility }\end{array}$ \\
\hline 7.4.2011 & 1:45 p.m. CET & 0,50 & 1,25 & 2,00 \\
\hline 7.7.2011 & 1:45 p.m. CET & 0,75 & 1,50 & 2,25 \\
\hline 3.11 .2011 & 1:45 p.m. CET & 0,50 & 1,25 & 2,00 \\
\hline 8.12 .2011 & 1:45 p.m. CET & 0,25 & 1,00 & 1,75 \\
\hline 5.7 .2012 & 1:45 p.m. CET & 0,00 & 0,75 & 1,50 \\
\hline 2.5 .2013 & 1:45 p.m. CET & 0,00 & 0,50 & 1,00 \\
\hline 7.11 .2013 & 1:45 p.m. CET & 0,00 & 0,25 & 0,75 \\
\hline 5.6 .2014 & 1:45 p.m. CET & $-0,10$ & 0,15 & 0,40 \\
\hline 4.9.2014 & 1:45 p.m. CET & $-0,20$ & 0,05 & 0,30 \\
\hline 22.1 .2015 & 2:30 p.m. CET & \multicolumn{3}{|c|}{ QE announcement } \\
\hline 5.3 .2015 & 2:30 p.m. CET & \multicolumn{3}{|c|}{ QE details announcement } \\
\hline 3.12 .2015 & 1:45 p.m. CET & $-0,30$ & 0,05 & 0,30 \\
\hline
\end{tabular}

Panel B: FOMC meetings

\begin{tabular}{|c|c|c|}
\hline $\begin{array}{l}\text { Date of the } \\
\text { FOMC } \\
\text { meeting }\end{array}$ & $\begin{array}{c}\text { Time of the } \\
\text { announcement }\end{array}$ & Unconventional monetary policy settings \\
\hline 21.9.2011 & 8:00 p.m. CET & $\begin{array}{l}\text { FOMC meeting with the announcement of operation Twist planning to purchase } \\
400 \text { billion dollars of bonds with maturities of } 6 \text { to } 30 \text { years and to sell the bond } \\
\text { within less than } 3 \text { years, thereby extending the average maturity of the Fed's } \\
\text { own portfolio. }\end{array}$ \\
\hline 20.6.2012 & 8:00 p.m. CET & $\begin{array}{l}\text { FOMC announced an extension to the Twist program by adding } 267 \text { billion } \\
\text { dollars. }\end{array}$ \\
\hline 13.9.2012 & 8:00 p.m. CET & $\begin{array}{l}\text { FOMC announced the 3rd round of the Quantitative Easing program (QE3) with } \\
\text { monthly purchases worth } 40 \text { billion dollars of mortgage-backed securities. }\end{array}$ \\
\hline 12.12.2012 & 8:00 p.m. CET & $\begin{array}{l}\text { FOMC voted to expand its QE program with an additional monthly } 45 \text { billion } \\
\text { USD of longer-term Treasury securities. }\end{array}$ \\
\hline 18.12 .2013 & 8:00 p.m. CET & $\begin{array}{l}\text { FOMC announced tapering back QE3 purchases at a rate of } 10 \text { billion USD } \\
\text { each month. }\end{array}$ \\
\hline 16.12.2015 & 8:00 p.m. CET & $\begin{array}{l}\text { FOMC announced its key interest rate (the Fed Fund rate) increase for the first } \\
\text { time after June } 2006 \text {. The hike was from the range }(0 \%-0.25 \%) \text { to the range } \\
(0.25 \%-0.5 \%) \text {. }\end{array}$ \\
\hline
\end{tabular}

